\title{
Generation Z's Perceptions and Attitudes towards Tourism and Hospitality a Career Option - A Preliminary Investigation of Residents of Jharkhand
}

Dr. Amar Kumar Chaudhary

Senior Faculty Member, University Department of Commerce and Business Management, Ranchi University, Ranchi, Jharkhand,India Vidya Jha

Faculty, Department of BBA \& MBA, Ranchi Women's College, Ranchi, Ranchi University, Ranchi, Jharkhand, India

\begin{abstract}
:
The purpose of this study is to examine the attitudes and perceptions of Generation $\mathrm{Z}$ of Jharkhand, India towards careers in the tourism industry. The study is exploratory and based on a quantitative approach. A total of 196 respondents have been selected by random sampling from all the districts of Bihar and Jharkhand for this study. Areas that students have concerns over include respondent's relationship with their managers, promotion opportunities, career paths, and the pay and conditions offered with in the industry. The study also focuses about the awareness of Gen Z about the Indian Tourism Development Programs, Jharkhand Tourism and the various regulations implemented in tourism sector. The data was collected by with the help of Google forms. The analysis has been done using Statistical Package for the Social Sciences (SPSS) software. The research shows that the Gen Z is good tourists but they have their doubts on taking up career in tourism sector. Though, they are inclined in doing so if this sector is more digital savvy, have good career development opportunities and if the tourism sector in Jharkhand is improved.
\end{abstract}

Keywords:

Gen Z, Jharkhand, Tourism, Career Development, Job

Article Received: 18 October 2020, Revised: 3 November 2020, Accepted: 24 December 2020

\section{Introduction}

"In 1995, the Internet was born. So, too, was Generation Z. With so many books, articles, and research studies focused on Millennials, this younger, lesser-known generation grew up right before our eyes without much fanfare."

(Seemiller and Grace 2017)

Gen $\mathrm{Z}$ is the newest generation to be named. Born between 1997 and 2012/15, they are currently between 8-24 years old. (Dimock 2019) (Smith and Cawthon 2017) Generation $Z$, or Gen $Z$ for short, is the demographic cohort succeeding the Millennials (or Gen Y). Demographers and researchers like (Kasasa 2020) typically use the mid- to late-1990s as starting birth years, while consensus has not been reached on the ending birth years. It started with Generation X, people born between 1965-1980. The preceding generation was the Baby Boomers, born 1946-1964. A flurry of potential labels has appeared, including Gen Tech,
post-Millennials, iGeneration, and $\mathrm{Gen} \mathrm{Y}-\mathrm{Fi}$, and Zoomers. According to a report by ConsumerLab, India has roughly 200 million children under the age of 18, and 69 million of them reside in urban areas. These young people have a very different childhood to the one their parents experienced.

The study also adds that 40 per cent of urban children regularly dine out at expensive restaurants and 23 per cent use their parents' credit cards to buy new things. Children of Generation $X$ and sometimes Millennials, members of Generation $\mathrm{Z}$ have used digital technology since a young age and are comfortable with the Internet and social media, but are not necessarily digitally literate. (Geck 2006) offers ideas and strategies to update library instruction and services using the Internet for Generation Z students. Born in or after 1990, these young people are unique because their birth coincides with the introduction of the graphical Web that resembles the Internet of today. These 
adolescents are amateur Internet searchers lacking skills in evaluating Web content and using resources other than popular Internet search tools such as Goggle. The Internet can be a perfect medium to introduce and develop information literacy skills because these youngsters will be receptive to any sort of instruction that makes them appear Web savvier.

"Because their use of technology has developed the visual ability portion of their brains, visual forms of learning are more effective for these learners. Furthermore, the use offast-paced multimedia has affected the ability of these learners to focus and analyze complex information. Also, technology use has had a significant impact on attention span."

\section{-(Rothman 2014)}

Realistically, the name Generation $\mathrm{Z}$ is a placeholder for the youngest people on the planet. It is likely to morph as they leave childhood and mature into their adolescent and adult identities. Generation $\mathrm{Z}$ is the ones filled with new aspirations and dreams towards a very rewarding career prospects. They have been technology savvy right from their childhood days. This generation has grown by knowing all about technology boom and probably all have studied on tablets and laptops. Yet, they are the ones growing up in the phase of nuclear families, parents losing job and have even seen the affect corona pandemic affect their studies and their parents struggle with job. Hence, for this generation job security, work life balance and attaining employability skills have become very crucial factors. This generation is way more distinct from their preceeding generations in respect of their characteristics, gender equality, income equality, perception towards their work. Researchers like

(Rothman 2014)(Törőcsik, Szücs, and Kehl 2014)(Mowforth 2018)(Anon 2016)(Maloni, Hiatt, and Campbell 2019)(Robinson and Schänzel 2019) (Törőcsik et al. 2014)(Turner 2015)(Bejtkovsky 2016)(Journal 2016)(Schroth
2019) have conducted study to get an insight about the career aspirations of Generation $\mathrm{Z}$ and also to learn how technology and social acceleration affect their career choice.

Tourism is a dynamic and competitive industry that requires the ability to adapt constantly to customers' changing needs and desires, as the customer's satisfaction, safety and enjoyment are particularly the focus of tourism businesses. India is a large market for travel and tourism. It offers a diverse portfolio of niche tourism products - cruises, adventure, medical, wellness, sports, MICE, ecotourism, film, rural and religious tourism. India has been recognized as a destination for spiritual tourism for domestic and international tourists. In his Independence speech from Red Fort, Prime Minister Narendra Modi urged people to visit 15 domestic tourist destinations in India by 2022 to promote tourism. India ranked 34 in the Travel \& Tourism Competitiveness Report 2019 published by the World Economic Forum. Total contribution by travel and tourism sector to India's GDP is expected to increase from Rs 15.24 lakh crore (US\$ 234.03 billion) in 2017 to Rs 32.05 lakh crore (US\$ 492.21 billion) in 2028. Total earning from the sector in India is targeted to reach US\$ 50 billion by 2022 . During 2019, foreign tourist arrivals (FTAs) in India stood at 10.89 million, achieving a growth rate of 3.20 per cent y-o-y. During 2019, FEEs from tourism increased 4.8 per cent $\mathrm{y}-\mathrm{o}-\mathrm{y}$ to Rs $1,94,881$ crore (US\$ 29.96 billion). In 2019, arrivals through e-Tourist Visa increased by 23.6 per cent $y-0-y$ to 2.9 million.

Under the Swadesh Darshan scheme, 77 projects have been sanctioned of worth Rs 6,035.70 crore (US\$ 863.60 million). In Union Budget 2020-21, the Government has allotted Rs 1,200 crore (US\$ 171.70 million) for the development of tourist circuits under Swadesh Darshan for Northeast. The launch of several branding and marketing initiatives by the Government of India such as 'Incredible 
India!' and 'Athiti Devo Bhava' has provided a focused impetus to growth. The Indian Government has also released a fresh category of visa - the medical visa or M-visa, to encourage medical tourism in the country. The Government is working to achieve one per cent share in world's international tourist arrivals by 2020 and two per cent share by 2025 . The Government is also making serious efforts to boost investment in the tourism sector. In the hotel and tourism sector, 100 per cent FDI (Foreign Direct Investment) is allowed through the automatic route. A five-year tax holiday has been offered for 2-, 3- and 4-star category hotels located around UNESCO World Heritage sites (except Delhi and Mumbai). Hotel and Tourism sector received cumulative FDI inflow of US\$ 15.28 billion between April 2000 and March 2020. In Union Budget 2019-20, the Government introduced a Tax Refund for Tourists (TRT) scheme in line with countries like Singapore to encourage tourists to spend more in India and boost tourism. The Government of India also announced to develop 17 iconic tourist sites in India into worldclass destinations as per Union Budget 2019-20. India is the most digitally advanced traveller nation in terms of digital tools being used for planning, booking, and experiencing a journey. India's rising middle class and increasing disposable income has supported the growth of domestic and outbound tourism.

International hotel chains are increasing their presence in the country, and it will account for around 47 per cent share in the tourism and hospitality sector of India by 2020 and 50 per cent by 2022 . India was globally the third largest in terms of investment in travel and tourism with an inflow of US\$ 45.7 billion in 2018, accounting for 5.9 per cent of the total investment in the country. The Indian Government has realised the country's potential in the tourism industry and has taken several steps to make India a global tourism hub.
Some of the major initiatives planned by the Government of India to boost the tourism and hospitality sector of India are as follows:

Ministry of Tourism launched DekhoApnaDesh webinar series to provide information on many destinations and sheer depth and expanse on the culture and heritage of India.

Ministry of Tourism launched Audio Guide facility App called Audio Odigos for 12 sites in India (including iconic sites).

Prime Minister, Mr Narendra Modi urged people to visit 15 domestic tourist destinations in India by 2022.

Statue of Sardar Vallabhbhai Patel, also known as 'Statue of Unity', was inaugurated in October 2018. It is the highest standing statue in the world at a height of 182 metre. It is expected to boost the tourism sector in the country and put it on the world tourism map.

Government of India is working to achieve one per cent share in world's international tourist arrivals by 2020 and 2 per cent share by 2025 .

Under Budget 2020-21, the Government of India has allotted Rs 1,200 crore (US\$ 171.70 million) for development of tourist circuits under Swadesh Darshan for eight Northeast states.

Under Budget 2020-21, the Government of India has allotted Rs 207.55 crore (US\$ 29.70 million) for development of tourist circuits under PRASHAD scheme.

In 2019, Government reduced GST on hotel rooms with tariffs of Rs 1,001 (US\$ 14.32) to Rs 7,500 (US\$ 107.31) per night to 12 per cent and those above Rs 7,501 (US\$ 107.32) to 18 per cent to increase India's competitiveness as a tourism destination.

In September 2019, Japan joined a band of Asian countries, including Taiwan and Korea among others, to enter India's tourism market. 
India's travel and tourism industry has huge growth potential. The industry is also looking forward to the expansion of e-Visa scheme, which is expected to double the tourist inflow in India. India's travel and tourism industry has the potential to expand by 2.5 per cent on the back of higher budgetary allocation and low-cost healthcare facility according to a joint study conducted by Assocham and Yes Bank. Ministry of Tourism launched DekhoApnaDesh webinar in April 2020 to provide information on the many destinations and the sheer depth and expanse of the culture and heritage of Incredible India. Till August 17, 2020, 48 webinars were conducted under the series.

Tourism is a highly labour intensive sector in India. According to an estimate by the planning commission, for every million rupees invested in tourism sector, 89 jobs are created against 4 jobs in primary sector and 13 jobs in secondary sector. These locations need to be developed and also the residents of the state should be made aware of the employment opportunities due to tourist development. In an effort to make India an attractive destination for both international and domestic tourists, Ms. Nirmala Sitaraman, Finance Minister, Government of India proposed to allocate Rs 2,500 crores in 2020-21 for the tourism sector. Besides tourism, the Finance Minister also proposed to allocate Rs.3,150 crore for the Ministry of Culture while presenting the Union Budget 2020-21 in Parliamenton February 1, 2020. Various announcements during the budget presentation for different sectors will, directly and indirectly, the benefit to tourism and related sectors, especially through the major road, rail, inland waterways, and civil aviation infrastructure developmental measures throughout the country. The Finance Minister has announced that 100 more airports would be developed by 2024 to support the Udaan scheme.
She also remarked in her Budget presentation that India's Air traffic has grown rapidly as compared to the global average and the Air fleet number was expected to go up from the present 600 to 1200 during this time.

In order to have well-trained human resources in the disciplines of museology and archaeology, the Finance Minister proposed to establish the first Indian Institute of Heritage and Conservation with the status of a deemed university to operate under the Ministry of Culture. She said, "Acquisition of knowledge in disciplines such as museology and archaeology are essential for collecting and analysing scientific evidence of such findings and for dissemination through high-quality museums." Highlighting improved tourism revenues due to better rank, the Finance Minister said, "India had moved up from rank 65 in 2014 to 34 in 2019 in the Travel \& Tourism Competitive Index (World Economic Forum)." Due to this, she continued, "Foreign Exchange earnings grew 7.4\% to Rs.1.88 lakh crores for the period January 2019 from Rs.1.75 lakh crores." In a major bid to revitalise tourism, Mrs. Nirmala Sitharaman proposed eight new museums, which include building infrastructure around five Iconic Sites, besides proposing the renovation of 5 major museums across the length and breadth of India. Recognizing the role of States in the proposed scheme for growth and employment generation, Mrs. Nirmala said, "Growth of tourism directly relates to growth in employment. States have a critical role to play. I expect State Governments expected to develop a road map for certain identified destinations and formulate financial plans during 2021 against which specified grants will be made available to the States in 2020-21". since then there has always been an upward slope. 


\begin{tabular}{|l|c|c|}
\hline & States/Union Territories & previous year \\
\hline $\mathbf{2 0 0 0}$ & 220.11 & 15.4 \\
\hline $\mathbf{2 0 0 1}$ & 236.47 & 7.4 \\
\hline $\mathbf{2 0 0 2}$ & 269.60 & 14.0 \\
\hline $\mathbf{2 0 0 3}$ & 309.04 & 14.6 \\
\hline $\mathbf{2 0 0 4}$ & 366.27 & 18.5 \\
\hline $\mathbf{2 0 0 5}$ & 392.04 & 7.0 \\
\hline $\mathbf{2 0 0 6}$ & 462.44 & 18.0 \\
\hline $\mathbf{2 0 0 7}$ & 526.70 & 13.9 \\
\hline $\mathbf{2 0 0 8}$ & 563.03 & 6.9 \\
\hline $\mathbf{2 0 0 9}$ & 668.80 & 18.8 \\
\hline $\mathbf{2 0 1 0}$ & 747.70 & 11.8 \\
\hline $\mathbf{2 0 1 1}$ & 864.53 & 15.6 \\
\hline $\mathbf{2 0 1 2}$ & 1045.05 & 20.9 \\
\hline $\mathbf{2 0 1 3}$ & 1142.53 & 9.3 \\
\hline $\mathbf{2 0 1 4}$ & 1282.80 & 12.3 \\
\hline $\mathbf{2 0 1 5}$ & 1431.97 & 11.6 \\
\hline $\mathbf{2 0 1 6}$ & 1615.39 & 12.8 \\
\hline $\mathbf{2 0 1 7} *$ & 1657.55 & 2.6 \\
\hline $\mathbf{2 0 1 8} \#$ & 1853.79 & 11.8 \\
\hline $\mathbf{2 0 1 9}(\mathbf{P})$ & 2321.98 & 25.3 \\
\hline
\end{tabular}

*: Revised in August, 2019 P: Provisional \# Revised in June 2020

Table 1.1 : Number of Domestic Tourist Visits to all States/Union Territories in India, 2000-2019

Table 1.1 gives the number of Foreign Tourist Arrivals, NRI arrivals and International Tourist Arrivals in India with the corresponding growth over previous year. The NRI arrivals in India has also increased from 5.43 millions in 2014 to 6.98 millions in 2019 showing a total increase of $26.7 \%$ over last 5 years. Though, the international tourist arrivals to India have shown an unusual pattern. The number of International Tourists Arrivals was 5.0 millions in 2015 which increased to 11.8 millions in 2017 but again decreased to 2.8 millions in 2019.

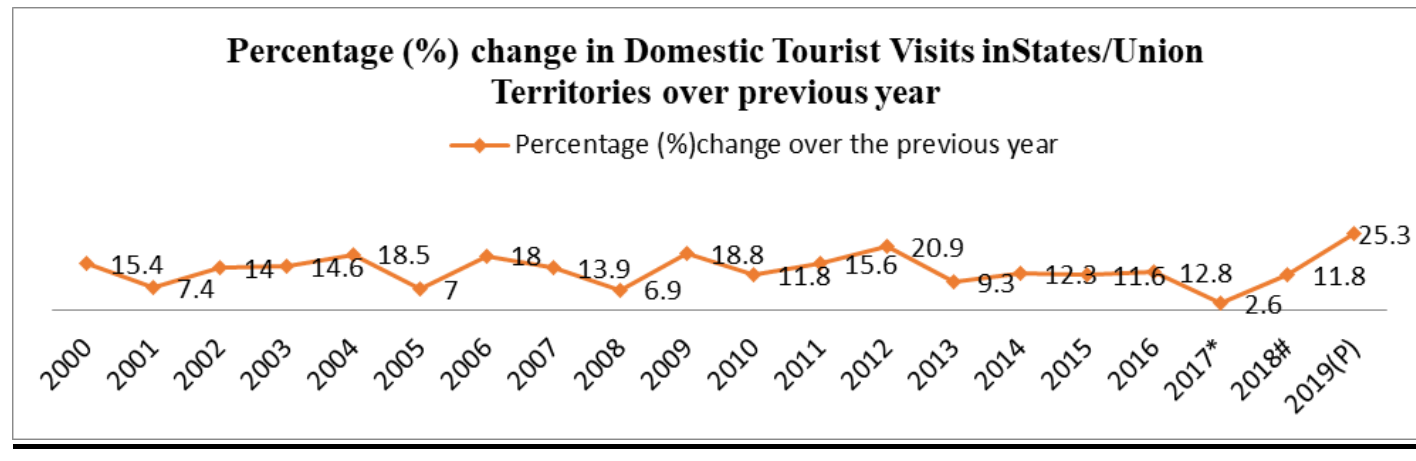
*: Revised in August, 2019
P: Provisional
\# Revised in June 2020

Figure 1:1 Percentage (\%) change in Domestic Tourist Visits (in million) to States/Union Territories over previous year 


\begin{tabular}{|l|c|c|c|c|c|c|}
\hline Year & $\begin{array}{c}\text { FTA in } \\
\text { India } \\
\text { (in } \\
\text { Millions) }\end{array}$ & $\begin{array}{c}\text { Percentage } \\
(\%) \text { change } \\
\text { over } \\
\text { previous } \\
\text { year }\end{array}$ & $\begin{array}{c}\text { NRIs } \\
\text { arrivals in } \\
\text { India }\end{array}$ & $\begin{array}{c}\text { Percentage } \\
(\%) \text { change } \\
\text { over } \\
\text { previous } \\
\text { year }\end{array}$ & $\begin{array}{c}\text { International } \\
\text { Tourist } \\
\text { Arrival in } \\
\text { India (in } \\
\text { Millions) }\end{array}$ & $\begin{array}{c}\text { Percentage } \\
(\%) \text { change } \\
\text { over } \\
\text { previous } \\
\text { year }\end{array}$ \\
\hline $\mathbf{2 0 0 1}$ & 2.54 & -4.2 & - & - & - & - \\
\hline $\mathbf{2 0 0 2}$ & 2.38 & -6.0 & - & - & - & - \\
\hline $\mathbf{2 0 0 3}$ & 2.73 & 14.3 & - & - & - & - \\
\hline $\mathbf{2 0 0 4}$ & 3.46 & 26.8 & - & - & - & - \\
\hline $\mathbf{2 0 0 5}$ & 3.92 & 13.3 & - & - & - & - \\
\hline $\mathbf{2 0 0 6}$ & 4.45 & 13.5 & - & - & - & - \\
\hline $\mathbf{2 0 0 7}$ & 5.08 & 14.3 & - & - & - & - \\
\hline $\mathbf{2 0 0 8}$ & 5.28 & 4.0 & - & - & - & - \\
\hline $\mathbf{2 0 0 9}$ & 5.17 & -2.2 & - & - & - & - \\
\hline $\mathbf{2 0 1 0}$ & 5.78 & 11.8 & - & - & - & - \\
\hline $\mathbf{2 0 1 1}$ & 6.31 & 9.2 & - & - & - & - \\
\hline $\mathbf{2 0 1 2}$ & 6.58 & 4.3 & - & - & - & - \\
\hline $\mathbf{2 0 1 3}$ & 6.97 & 5.9 & - & - & - & - \\
\hline $\mathbf{2 0 1 4}$ & 7.68 & 10.2 & 5.43 & - & 13.11 & - \\
\hline $\mathbf{2 0 1 5}$ & 8.03 & 4.5 & 5.74 & 5.7 & 13.76 & 5.0 \\
\hline $\mathbf{2 0 1 6}$ & 8.80 & 9.7 & 6.22 & 8.5 & 15.03 & 9.2 \\
\hline $\mathbf{2 0 1 7}$ & 10.04 & 14.0 & 6.77 & 8.8 & 16.81 & 11.8 \\
\hline $\mathbf{2 0 1 8}$ & 10.56 & 5.2 & 6.87 & 1.4 & 17.42 & 3.7 \\
\hline $\mathbf{2 0 1 9}$ & 10.93 & 3.5 & 6.98 & 1.7 & 17.91 & 2.8 \\
\hline
\end{tabular}

*Figures updates as in June 2020

Table 1.2: Inbound Tourism in India

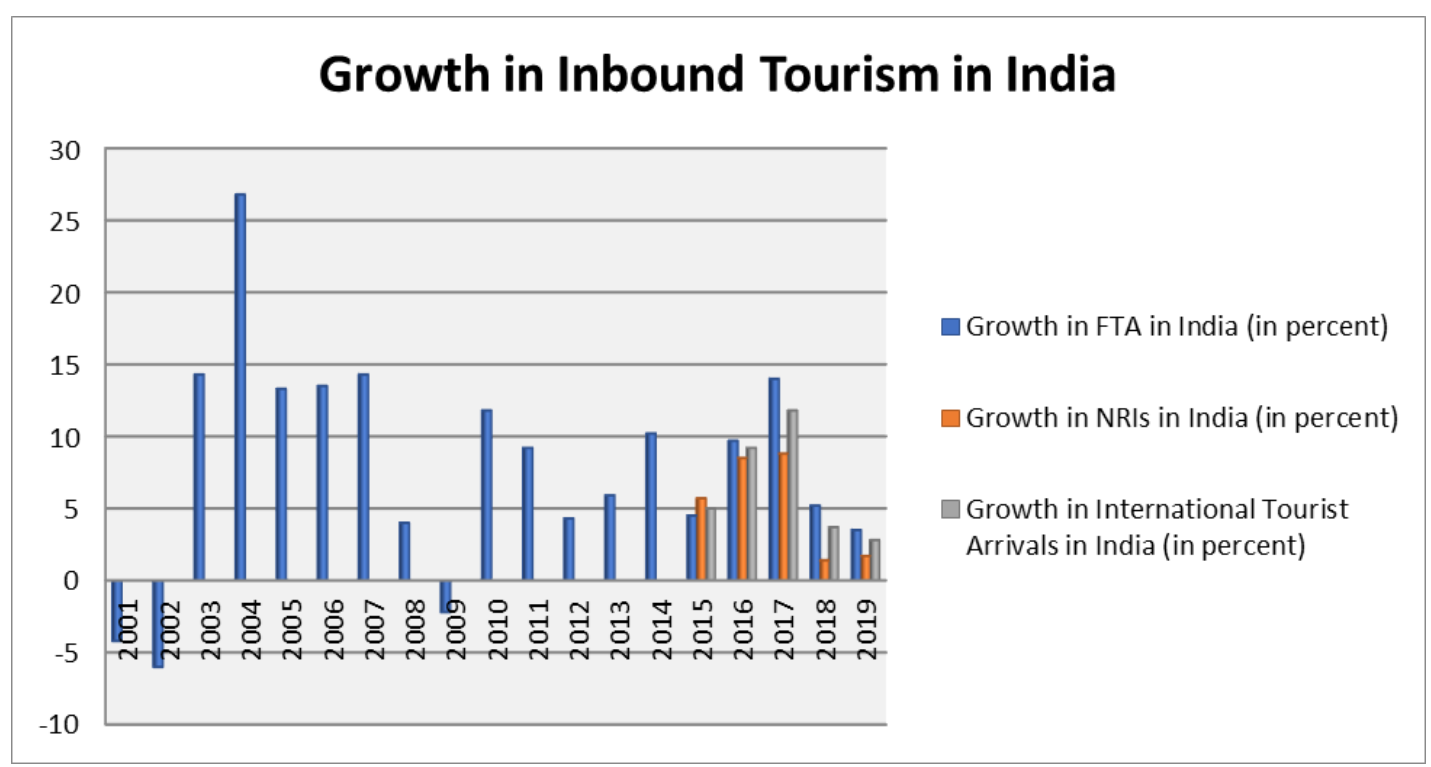

*Figures updates as in June 2020

Figure 1.2: Growth in Inbound Tourism in India 
The growth in FTAs in India has never had a consistent pattern. The entire period from 2001 to 2019 has some significant ups and downs in the trends of Foreign Tourist Arrivals to India.

\section{Importance of the Study}

In Jharkhand, a newly formed state in India, tourism is one of the important industries owing to the state's natural beauty, wildlife, religious and heritage, tribal, cruise and mining tourism. The state has always been known for its scenic beauty and exotic locations. It has a tremendous scope for rural, eco, adventure and health tourism. (Arunmozhi and Panneerselvam 2013) One of the best places to visit for wildlife aficionados and nature lovers, Jharkhand is a state replete with a vast bounty of towering mountains, dense forests and gushing waterfalls. Blessed with a plethora of natural scenic vistas, Jharkhand is the place for lookout for a oneon-one rendezvous with unperturbed, untouched nature. There is more to Jharkhand than just its scenic landscapes though, with several museums, temples and wildlife reserves scattered around the state. Formerly a part of Bihar, Jharkhand was carved out as a separate state almost two decades ago, thus creating the base for a glorious history, diverse culture and tribal simplicity that the state can now call its very own.

Jharkhand is 'the land of forests' as its name suggests and the state is famous for its rich variety of flora and fauna. The scenic beauty of forests, hills and plateaus from the Lodh Falls leaves an enchanting impression on tourists while the lush green forests that surround the state keeps it green and clean. Nature is considered as a vital and essential part of the life of tribal people who dominate the state, and this is one of the reasons that you can have a panoramic view of nature and its beauty. Ranchi Hills, Daasam Falls, Sun Temple, Baidyanath Dham are some of the major tourist attractions in Jharkhand. The State Government has a firm belief that development of tourism sector would not only generate immense employment opportunities directly or indirectly but also contribute in accelerated economic development by raising the income level of the people. As a result of this, the State Government has accorded tourism the status of industry in Jharkhand. Around 1.4 crore foreign tourists visited India in 2017. In 2014 the figure was 76.8 lakhs. An annual growth of 14 percent was recorded. In 2019, the then Tourism Minister Amar Kumar Bauri had told that in the last four and a half years, the number of tourists visiting Jharkhand had doubled. The total number of tourists coming was 3.54 lakhs out of which the about 1.76 lakhs were foreign tourists. A total of 3.54 crore tourists have visited Jharkhand in the last four and a half years, state Tourism Minister Amar Bauri has said. He said under the "Swadesh Darshan Scheme" of the Central government Rs 52.72 crore will be spent for development of Dalma-Chandil-GetalsudBetla, Mirchainia, Netarhat eco tourism circuit in the state.

"The number of tourists coming to Jharkhand has doubled in the last four and a half years. This number has increased to 3.54 crore. It has approximately 1.76 lakh foreign tourists. Basic amenities have been made available in the state's major tourist destinations and it has also provided employment to 74.16 thousand people of the state," said the minister.

He said 132 tourist sites of the state are being developed by classifying them in international, national, state-level and local-level categories, adding eight tourists and cultural sports festivals are being organised by according them the status of state festivals. The eight festivals are - Itkhori Festival, Chhau Festival, Baidyanath Dham Festival, Luguburu Festival, Maghi Mela, Hijala Mela, Mudma Mela and Basukinatham Festival.The minister said the efforts made by the government enabled the month-long "Shravani Mela" in 
Deoghar getting international recognition. He said work to preserve terracotta temples located in Maluti in Dumka is in progress. A lot of work has been done in the field of creativity and innovation for increasing the productivity of the organization.

Tourism is highly labour intensive industry, the working hours for the people in this sector are more than normal and the pay is minimal. The holiday's seasons are the most hectic season for the employees. When everyone is in their holiday and festive spirits, the employees of this sector are the ones most occupied in their jobs. To keep the employees on job and that too, motivated, is a very tedious task. This sometimes leads to high labour turnover and absenteeism. Hence, strategic management of the human resources is very crucial, to keep them committed to their job and increase the employees affinity towards their workplace. There is a direct relation between proper career management and job satisfaction. (Adekola 2011) in his study empirically investigated and established the direct influence of career planning and career management on career development and the subsequent effect on job satisfaction and career commitment. So, proper career planning and career development can be one of the strategic stops toward human resource development.

Post World War II, Americans were enjoying newfound prosperity, which resulted in a "baby boom." The children born as a result were dubbed the Baby Boomers. But the generation that followed the Boomers didn't have a blatant cultural identifier. In fact, that's the anecdotal origin of the term Gen $\underline{X}$ - illustrating the undetermined characteristics they would come to be known by. Depending on whom you ask, it was either sociologists, a novelist, or Billy Idol who cemented this phrase in our vocabulary. From there on it was all down-alphabet. The generation following Gen $\mathrm{X}$ naturally became Gen Y, born 1981-1996 (give or take a few years on either end). The term "Millennial" is widely credited to Neil Howe, along with William Strauss. The pair coined the term in 1989 when the impending turn of the millennium began to feature heavily in the cultural consciousness.

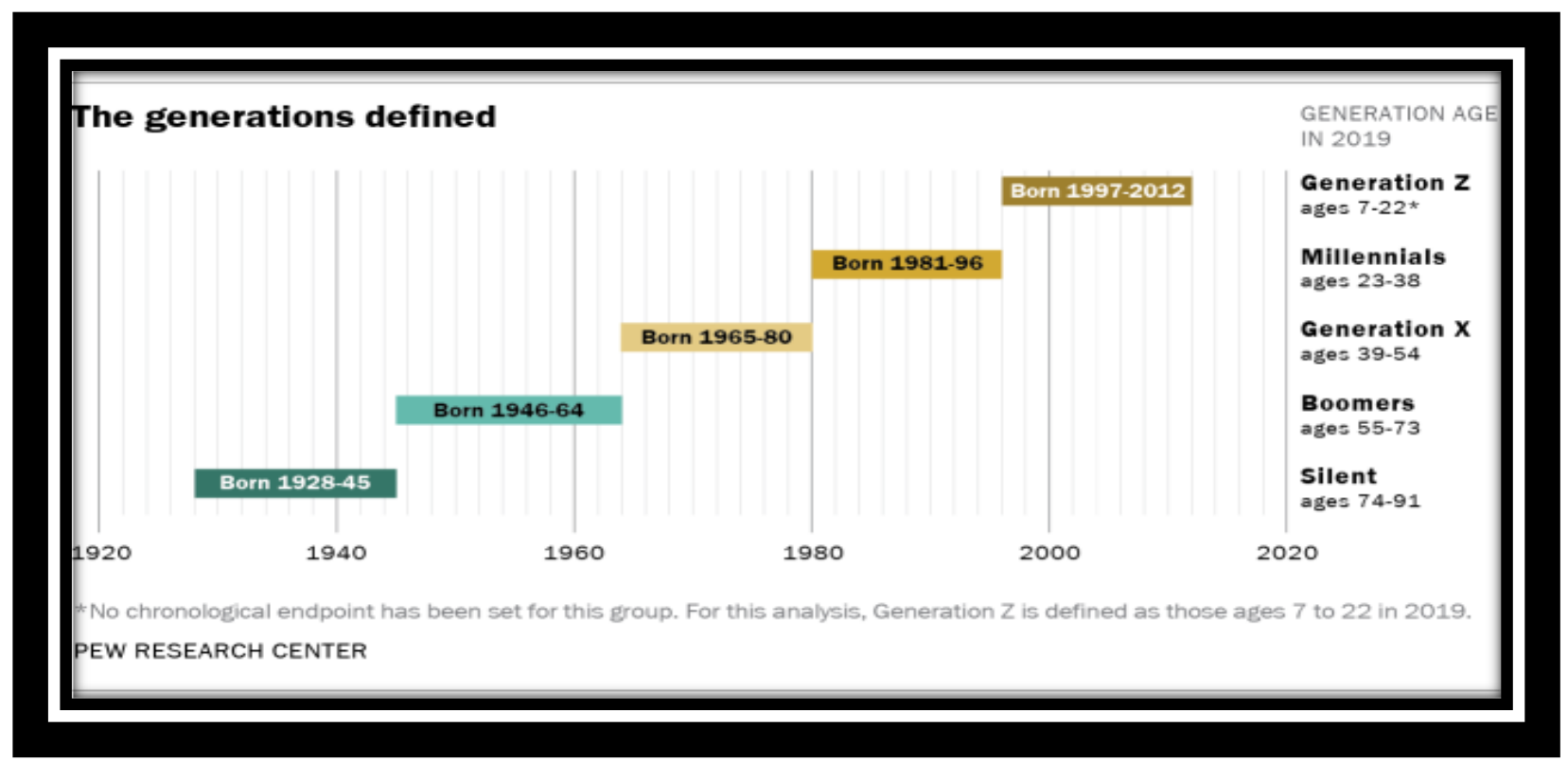

Figure 2.1: The Generations Defined 
Generation $\mathrm{Z}$ refers to babies born from the mid2000s through today, although the term isn't yet widely used. This may signal the end of 'alphabet soup' (it does coincide with the literal end of the alphabet, after all). Each generation label serves as a short-hand to reference nearly 20 years of attitude, motivations, and historic events. Few individuals self-identify as Gen X, Millennial, or any other name. They're useful terms for marketers and have a tendency to trickle down into common usage. Again, it's important to emphasize that referring to a cohort simply by the age range gets complicated quickly. 10 years from now, the priorities of Millennials will have changed - and marketing tactics must adjust instep. There are also other categories of cohorts you can use to better understand consumers outside of age that may work better for your purposes.

Generation is a very headstrong generation adamant at crafting their own way towards future. They do idolize their elders of Generation X and Generation $\mathrm{Y}$ but they make up their mind form their adolescents towards shaping their career in their own unique way. They are too much into social media and are always stuck in their virtual world, yet are the ones who believe that they can make making significant societal changes. They also have a vast knowledge base due their exposure to internet from the early childhood and hence have a unique approach towards life and career. Survival of hospitality and tourism industry is highly dependent on a stable workforce to serve the tourists and customers. In a shrinking workforce market faced with traditionally high staff turnover and increased departure of the older workers, strategy should be developed to retain next Generation hospitality talent - Generation Z. (Goh and Okumus 2020) Hence, to educate, recruit and to retain them and also to decrease absenteeism and labour turnover, the organizations would have to develop their unique strategic human resource development
(SHRM) practices. Generation $\mathrm{Z}$ has always been taught and does realize the importance of aligning their objective with the objectives of the organization for overall growth, but their rebellious nature and the plethora opportunities available today has made retaining and attracting workforce is a very challenging task. Surveys have shown than Generation $\mathrm{Z}$ today prefers random experiences. They are all about practicality, reality and experiences. (LEVI 2015)(Adecco 2015)(Fister Gale 2015)

The research on career aspects of Generation $\mathrm{Z}$ is extremely limited and almost no work could be found on the attitude and perceptions of Gen $\mathrm{Z}$ towards taking tourism as a career option. Most of the literature survey is based on the studies by authors on countries other than India. Though the people of certain age group do have certain common characteristics, but they do differ widely based on their demographic factors, the accessibility to technology and education.

\section{Objective to the study}

To study the attitude and perception of Gen $\mathrm{Z}$ towards career in tourism sector.

To study the attitude and perception of Gen $\mathrm{Z}$ towards career in tourism sector in Jharkhand.

To study the awareness of the Gen $\mathrm{Z}$ about the various Government schemes in tourism sector

To study the motivating and demotivating factors of Gen $\mathrm{Z}$ towards taking up tourism as a career.

\section{Literature Review}

Larry Rosen, a professor at CSU Dominguez Hills who teaches a class called Global Impact of Technology, says of Gen Z students, "They are very collaborative and creative. They will change the workplace dramatically in terms of work style and expectations. " (Posnick-Goodwin 2010) 
Building a personal brand in this modern age, where technology and social platforms redefine the way individuals interact, has become a necessity, especially for the young generation $\mathrm{Z}$ which are increasingly involved in the online medium. A personal brand conveys an individual's identity and distinctiveness and it has become an important tool for young individuals that enables them to achieve success regardless of their status: they can be young professionals in search for a job, public speakers, bloggers, managers or entrepreneurs at the beginning of their career via development of personal branding tools and social media platforms, such as Facebook, Instagram or LinkedIn.(VITELAR 2013). Generation $Z$ is a digital generation. (Kapil and Roy 2014)

(Chillakuri and Mahanandia 2018) emphasizes that it is critical for the organization to revisit their strategies so as to accommodate this cohort group. With Generation $\mathrm{Z}$ entering the workforce, the nature of entry-level jobs is changing; hence, HR needs to redesign their strategies to attract and engage Generation Z. Researchers and academicians have done studies to find out ways in which Generation X and Generation Y can have a positive influence on Gen Z. (Montana and Petit 2008)(Montana and Petit 2008)(Schroer and Klein 2008)(Tulgan 2013)(Schroer 2014)

Generation $\mathrm{Z}$ are accustomed to collaborate, share and distribute images and information. Besides, they are often described as instant minded with faster life rhythm, and tending to be more individualistic and self-directed. With the advent of technological innovations, the generation $\mathrm{Z}$ is constantly connected with their friends, peers, family, relatives and acquaintances. They are born and brought up with idea of a connected world and want to connect and share their accomplishments with all. This being said, the generation $\mathrm{Z}$ do not shy off from work and have a set of predefined ideologies towards their workplace. The workplace includes all the aspects such as team, superiors, subordinates, freedom of speech, etc.(Desai and Lele 2017)

Though tourism has huge employment prospects, but even the developed countries have problems regarding retaining employees in the tourism sector. According to the study on undergraduates in Australia by (Richardson 2010) areas that students have concerns over include respondent's relationship with their managers, promotion opportunities, career paths, and the pay and conditions on offer within the industry. Possibly the most alarming finding to come out of this study is that more than $50 \%$ of respondents are already contemplating careers outside the industry. Of those with work experience in the industry, $38.1 \%$ claim that they will not work in the tourism and hospitality industry after graduation, with $91.7 \%$ of these respondents' citing working experience in the industry as the main reason for this decision. (Barron et al. 2007) infers that hospitality industry needs to understand and respond to the characteristics of Generation Ys so as to enable them to develop their management careers in a way that is attractive to them. (Goh and Lee 2018)suggest Generation $Z$ viewed overall positive attitudes about the hospitality industry such as exciting, a people's industry with travel opportunities along with certain challenges such as dealing with people, long/odd hours and potential workplace health and safety issues.

According to (Fratricová and Kirchmayer 2018)(Anon 2016) enjoying one's work and team climate were also the top two factors accounting for both states of mind at work (positive work motivation as well as lack of it). The most frequently occurring factors cited in surveys on Generation Z such as options of career advancement and continuous learning/growth, generous rewards and chances of making a positive impact. (Singh 2014) research was based on the changing attitude, 
behavior of children, students and scholars of Gen Z of global scenario. According to him Gen $\mathrm{Z}$ is very active, motivated, goal oriented, extraordinary, competent, researcher, observer etc. They are fully awakened by the social responsibilities towards society, knowledge of laws, rules and regulation, they are extremely technology savvy, smart minded, challenging, adventurous, active decision maker, leadership skill and talented. They are smart in tricks and more enthusiasm to carry out the relative and difficult tasks. Still the area of wariness in front of each and every parents, teacher, mentors, counselor that what should be the atmosphere one should give generation $\mathrm{Z}$, so that they can grasp the values, ethics, listeners, proactive, customs, observers and derivative principles. Hence, the parents, teachers and mentors must adapt teaching strategies and incorporating technology to adapt the upcoming generation's mobile tech-savviness and self-directed learning, which often is accompanied by a lack of critical thinking skills.(Shatto and Erwin 2016)

The most prevalent barriers to work motivation emerging from respondents' stories are: not enjoying the content of the work, bad team climate, workload, and having no sense of purpose in the job. A prominent list of dichotomic (overlapping) factors in both motivators and barriers indicates that most respondents do not separate motivation drivers and barriers in two isolated groups. Enjoying one's work and team climate were also the top two factors accounting for both states of mind at work (positive work motivation as well as lack of it). The most frequently occurring factors cited in surveys on Generation Z such as options of career advancement and continuous learning/growth, generous rewards and chances of making a positive impact were all replicated in our study as well. (Fratricová and Kirchmayer 2018) Generations $Z$ seems to have different requirements and motivating factors then the earlier generations. This generation will stir its own unique needs upon the workplace as they enter the organizations. It is important for the organization to discover what's important to the Generation $\mathrm{Z}$ beforehand to boost attractiveness within and outside the industry in order to establish a corporate culture and workplace to gain a distinctive advantage in the hunt for top talent employees from the Generation $\mathrm{Z}$ which in turn will sustain the organizational growth and remain a winning organization throughout. (Singh and

\section{Dangmei 2016)}

The Z Generation of India comprising of $20.1 \%$ of the total population is predicted to bring about a drastic change in the upcoming workforce. By the end of this decade, the workplaces are slated to imbibe various differences to harness the distinct advantages this generation will bring to the productivity levels and faces of organizations worldwide. (Mathur and Hameed 2016) studies the behavioral competencies of the $\mathrm{Z}$ Generation which can be mapped to develop the managerial skills that are latent in their multi-tasking and technologically-savvy abilities. (Robert Half 2015) says that Generation $\mathrm{Z}$ tend to be entrepreneurial with an interest in social justice, research on Generation Z is presented by (Tapscott 1999) in his book "Grown Up Digital," and the role of Generation $\mathrm{Z}$ in technological innovation. As potential and current employees, Gen $\mathrm{Z}$ are not looking for life-long employment, put forward their specific values and expect the potential employer to attract them by meeting their needs in terms of flexible working hours, flexible (varied) jobs where their individuality can be applied, company excellent reputation, innovation, speed of change, platform for educational and promotional advancement, specific fringe benefits.(Sidorcuka and Chesnovicka 2017)

As a literature teacher, (Csobanka 2016) mentions personal examples to prove that it is important to take the new habits and specifics of teenagers into 
account in order to teach more efficiently. Reseaches have been done to study the kind of education to be imparted to the this new generation with ever changing demands such they have a competitive edge in the society. (Hariadi, Sunarto, and Sudarmaningtyas 2016)(Fernández-Cruz and Fernández-Díaz 2016)(Thomas and Srinivasan 2016)(Shatto and Erwin 2017) Most of the research work done on Generation $\mathrm{Z}$ is in reference to their preferences as customers, their effects on retailer(Wood 2013).(Bassiouni and Hackley 2014) (Merriman 2015)(Kvidahl 2015)(Baysinger 2015)(Hulyk 2015)(Puiu 2016)(Gutfreund 2016)(Priporas, Stylos, and Fotiadis 2017). Very little empirical study has been made in respect to tourism as a career option for Generation Z.

\section{Research Methodology}

Universe : The students of schools and colleges of Jharkhand whose age varies between 8 years and 24 years

Sample design: Random Sampling Method has been used.

Type of data: Researcher is going to use both primary and secondary data. This will consist of reports, records, manuals and other published literature

\section{Methods of data collection :}

- Online data survey

- Questionnaires

- $\quad$ Observation method

Data Analysis: Respondents from the age group of 8 to 24 years have been randomly selected. The questionnaire has been designed by the researcher based on the literature survey and observation method to determine the perception of Gen $\mathrm{Z}$ towards tourism as a career.

The data has been collected with the help of Google and forms and Google spreadsheet has been used to tabulate the form responses. The analysis is done using Statistical Package for the Social Sciences (SPSS) software where the frequencies were calculated and the charts were generated.

\section{Data Analysis and Results}

The data was collected by with the help of Google forms. The analysis is done using Statistical Package for the Social Sciences (SPSS) software Demographic Profile of the Respondents Table 6.1 and Figure 6.1 represents the frequency of the respondents by gender. $\quad(\mathrm{N}=196)$

Table 6.1: Frequency and percentage of the respondents by gender

\begin{tabular}{|l|l|l|l|l|l|}
\hline \multicolumn{9}{|c|}{ Sex } \\
\hline \multirow{3}{|c|}{} & Frequency & Percent & Valid Percent & Cumulative Percent \\
\hline \multirow{3}{*}{ Valid } & Female & 139 & 70.9 & 70.9 & 70.9 \\
\cline { 2 - 6 } & Male & 57 & 29.1 & 29.1 & 100.0 \\
\cline { 2 - 6 } & Total & 196 & 100.0 & 100.0 & \\
\hline
\end{tabular}




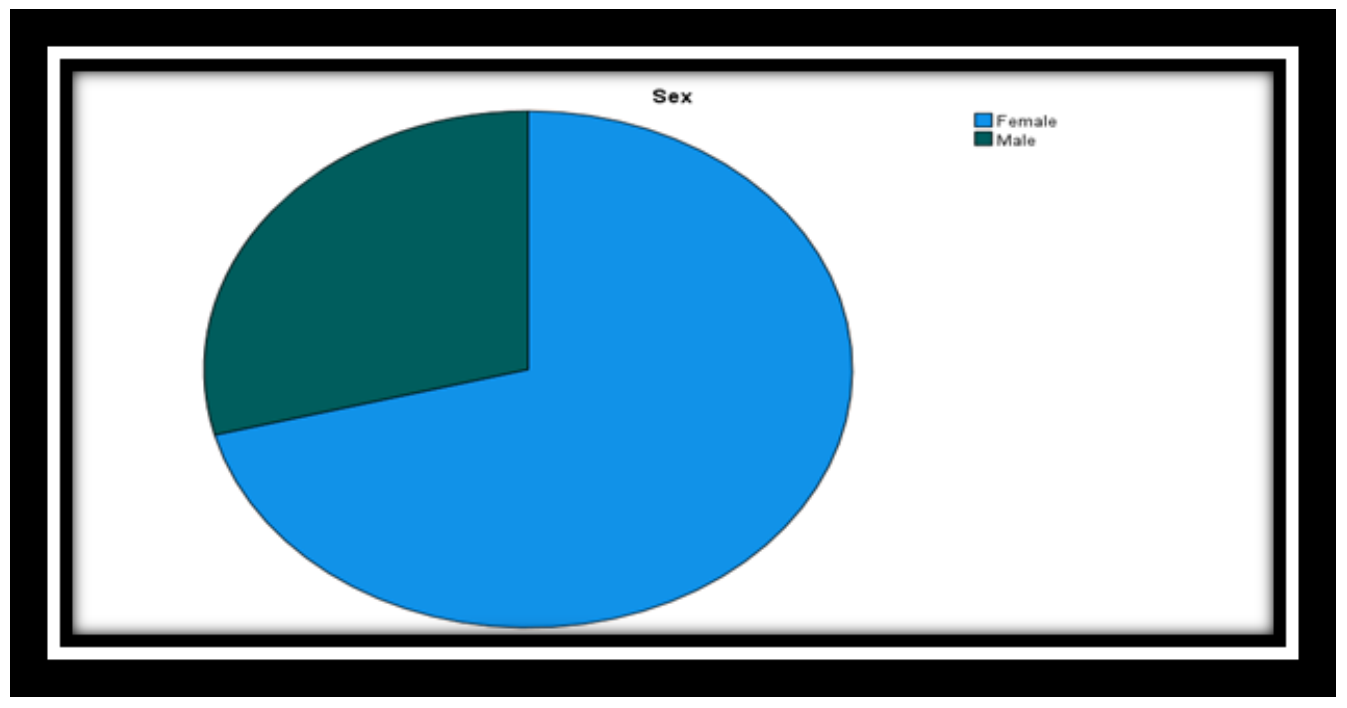

Figure 6.1: Frequency and percentage of the respondents by gender

Area of Residence - The respondents are from the various cities of Bihar and Jharkhand as Jharkhand is a newly formed state and has been a part of Bihar till 2000, maximum residents of Jharkhand are natives of Bihar or vice versa. Also, a lot of students in Jharkhand schools and colleges are residents of Bihar and vice versa.

\begin{tabular}{|c|c|c|c|c|c|}
\hline & & Frequency & Percent & Valid Percent & $\begin{array}{l}\text { Cumulative } \\
\text { Percent }\end{array}$ \\
\hline Valid & Adra & 1 & .5 & .5 & .5 \\
\hline & Aminabaad & 1 & .5 & .5 & 1.0 \\
\hline & Balangir & 1 & .5 & .5 & 1.5 \\
\hline & Ballia & 1 & .5 & .5 & 2.0 \\
\hline & Bihar & 1 & .5 & .5 & 2.6 \\
\hline & Bokaro & 4 & 2.0 & 2.0 & 4.6 \\
\hline & Buxar & 1 & .5 & .5 & 5.1 \\
\hline & Chaibasa & 15 & 7.7 & 7.7 & 12.8 \\
\hline & Chakradharpur & 2 & 1.0 & 1.0 & 13.8 \\
\hline & Daltonganj & 3 & 1.5 & 1.5 & 15.3 \\
\hline & Dhanbad & 1 & .5 & .5 & 15.8 \\
\hline & Durgapur & 1 & .5 & .5 & 16.3 \\
\hline & Garhwa & 1 & .5 & .5 & 16.8 \\
\hline & Gaya & 1 & .5 & .5 & 17.3 \\
\hline & Giridih & 1 & .5 & .5 & 17.9 \\
\hline & Gomia & 1 & .5 & .5 & 18.4 \\
\hline & Gumla & 3 & 1.5 & 1.5 & 19.9 \\
\hline & Hazaribag & 1 & .5 & .5 & 20.4 \\
\hline
\end{tabular}




\begin{tabular}{|c|c|c|c|c|}
\hline India & 1 & .5 & .5 & 20.9 \\
\hline Jamalpur & 1 & .5 & .5 & 21.4 \\
\hline Jamshedpur & 5 & 2.6 & 2.6 & 24.0 \\
\hline Kharaghpur & 1 & .5 & .5 & 24.5 \\
\hline Latehar & 1 & .5 & .5 & 25.0 \\
\hline Lohardaga & 1 & .5 & .5 & 25.5 \\
\hline Mc-cluskiegunj & 1 & .5 & .5 & 26.0 \\
\hline Mccluskeigunj & 1 & .5 & .5 & 26.5 \\
\hline Mirzapur & 1 & .5 & .5 & 27.0 \\
\hline Pada Pahar & 1 & .5 & .5 & 27.6 \\
\hline Patratu thermal & 1 & .5 & .5 & 28.1 \\
\hline purnea, bihar & 1 & .5 & .5 & 28.6 \\
\hline Ranchi & 136 & 69.4 & 69.4 & 98.0 \\
\hline Sahibganj & 3 & 1.5 & 1.5 & 99.5 \\
\hline Simdega & 1 & .5 & .5 & 100.0 \\
\hline
\end{tabular}

Table 6.2: Frequency and percentage of the respondents by the city of resident in Bihar and Jharkhand

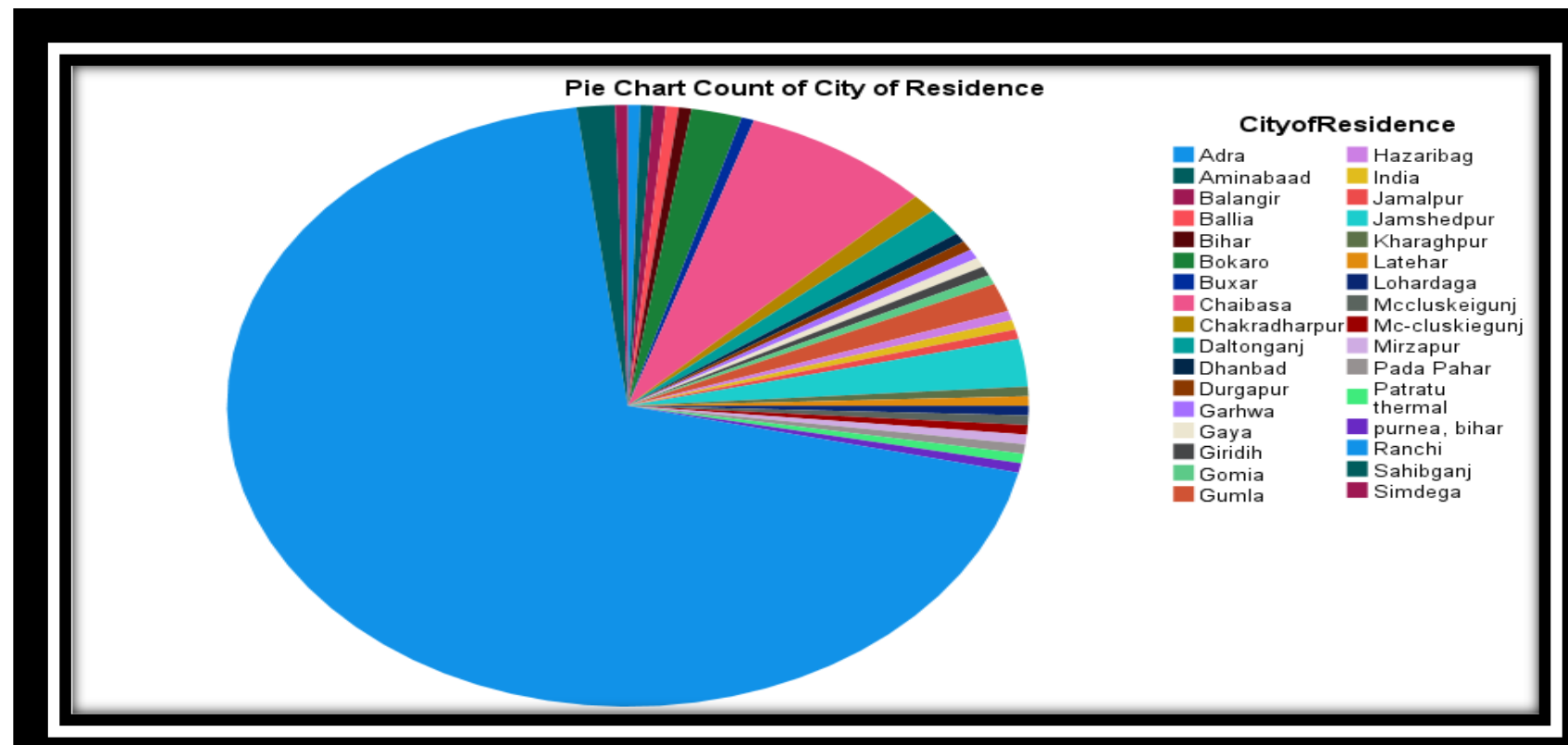

Figure 6.2: Frequency and percentage of the respondents by the city of resident in Bihar and Jharkhand

$\underline{\text { Exposure of the Generation } \mathrm{Z} \text { to the tourism Secto }}$

\begin{tabular}{|l|l|l|l|l|l|}
\hline \multicolumn{6}{|l|}{ Have you managed an event in your school/college/University } \\
\hline \multicolumn{2}{|l|}{ Valid } & Frequency & Percent & Valid Percent & Cumulative Percent \\
\cline { 2 - 6 } & Maybe & 16 & 8.2 & 8.2 & 8.2 \\
\hline & No & 58 & 29.6 & 29.6 & 37.8 \\
\hline
\end{tabular}




\begin{tabular}{|l|l|l|l|l|l|}
\hline \multirow{2}{*}{} & Yes & 122 & 62.2 & 62.2 & 100.0 \\
\cline { 2 - 6 } & Total & 196 & 100.0 & 100.0 & \\
\hline
\end{tabular}

Table 6.3: Frequency and percentage of respondents having managed an event in

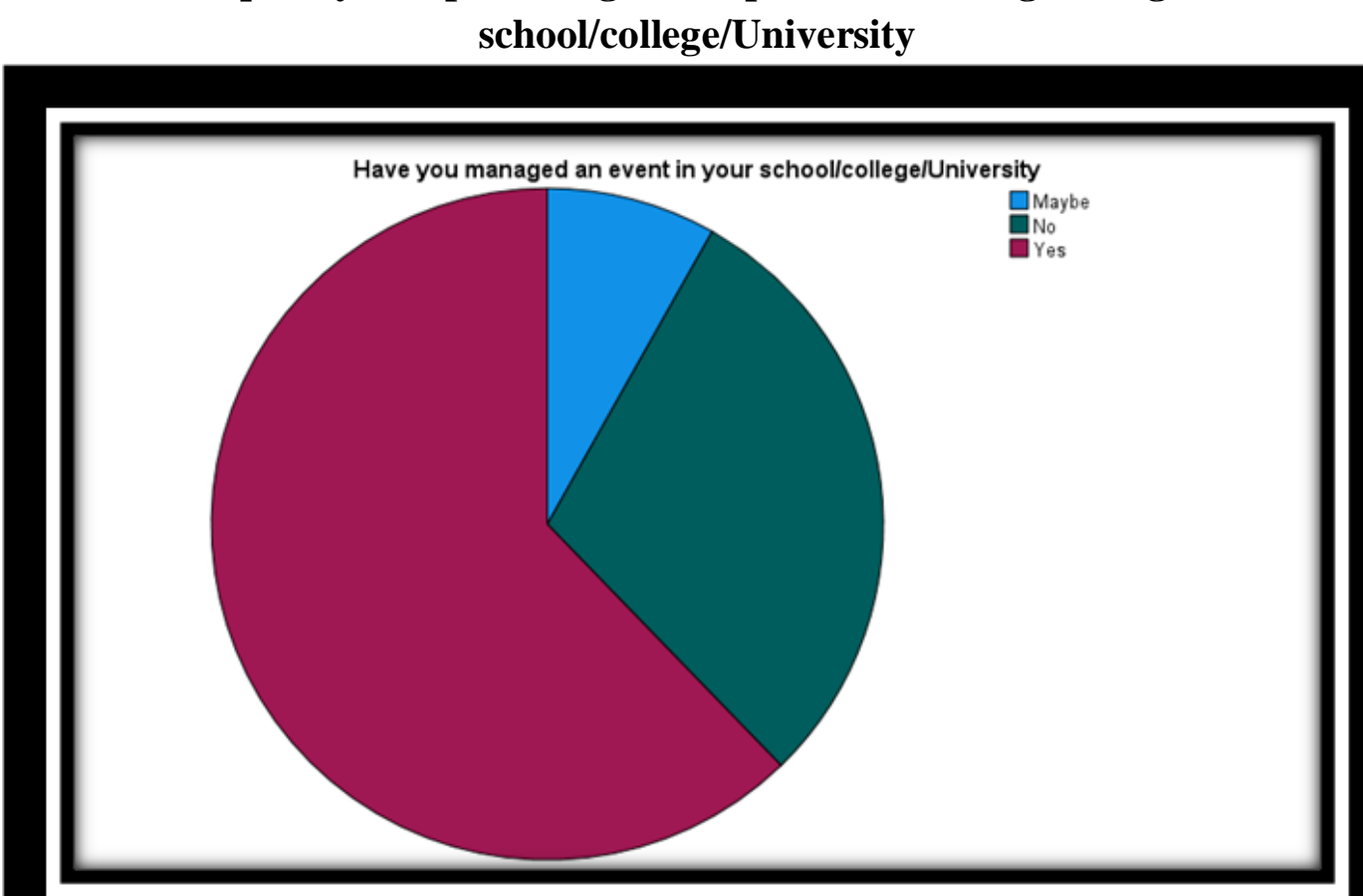

Figure 6.3: Frequency and percentage of respondents having managed an event in school/college/University

Have you ever worked in or have been associated with an event management?

\begin{tabular}{|l|l|l|l|l|l|}
\hline \multicolumn{2}{|c|}{} & Frequency & Percent & Valid Percent & Cumulative Percent \\
\hline \multirow{3}{*}{ Valid } & No & 157 & 80.1 & 80.1 & 80.1 \\
\cline { 2 - 6 } & Yes & 39 & 19.9 & 19.9 & 100.0 \\
\cline { 2 - 6 } & Total & 196 & 100.0 & 100.0 & \\
\hline
\end{tabular}

Table 6.4: Frequency and percentage of respondents having been associated with any event management 


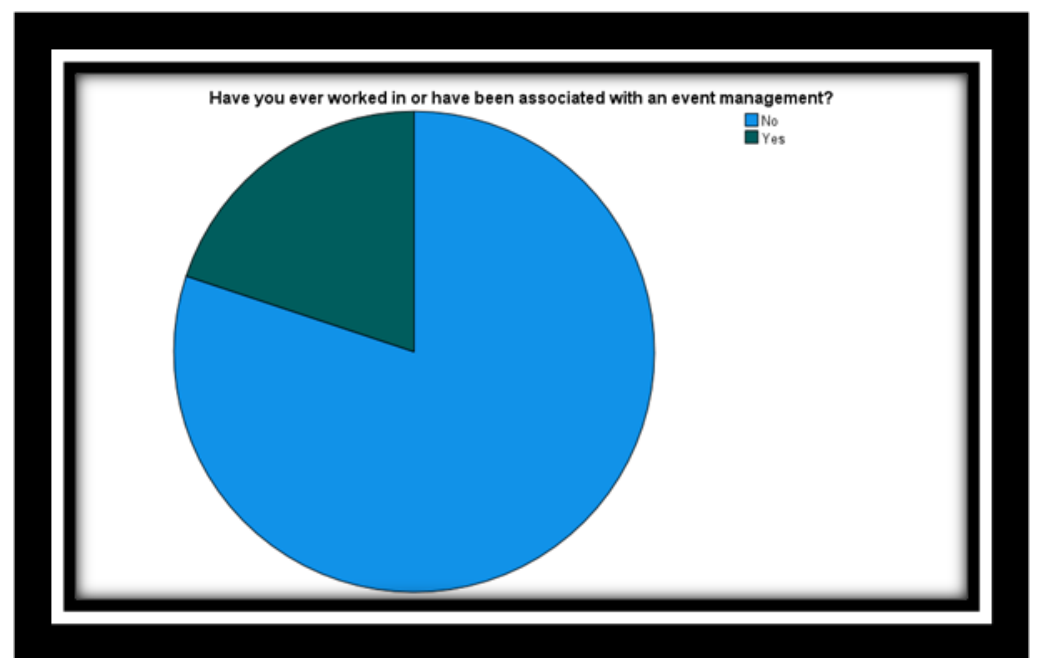

Figure 6.4: Frequency and percentage of respondents having been associated with any event management Awareness of Generation $Z$ about the various Tourism Development Programmes launched by the Indian Government

Table 6.5: Awareness of Generation $Z$ about the various Tourism Development Programmes launched by the

\begin{tabular}{|l|l|c|c|}
\hline \multicolumn{5}{|c|}{ Awareness of Generation Z about the various Tourism Development Programmes } \\
\hline Sl. No. & Government Scheme & Frequency & Percent \\
\hline 1. & Swadesh Darshan scheme & 58 & 29.6 \\
\hline 2 & Incredible India! & 135 & 68.9 \\
\hline 3 & Athiti Devo Bhava' & 122 & 62.2 \\
\hline 4 & Audio Odigos & 8 & 4.1 \\
\hline 5 & PRASHAD scheme. & 13 & 6.6 \\
\hline 6 & DekhoApnaDesh webinar & 24 & 12.2 \\
\hline 7 & None of the above & 25 & 12.8 \\
\hline
\end{tabular}

Indian Government 


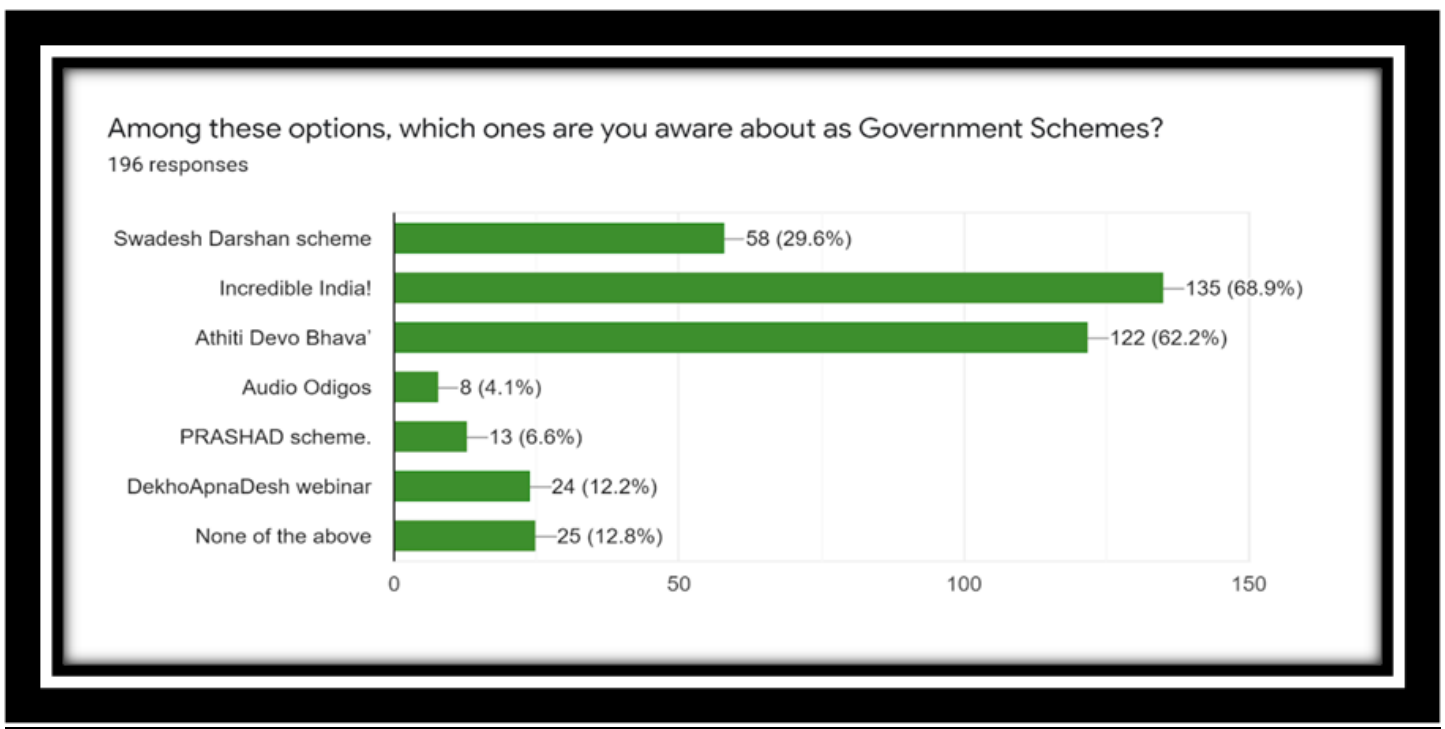

Figure 6.5: Awareness of Generation $\mathrm{Z}$ about the various Tourism Development Programmes launched by the Indian Government

Awareness of Generation $\mathrm{Z}$ about tourism in Jharkhand

\begin{tabular}{|c|c|c|c|c|c|}
\hline \multicolumn{6}{|c|}{ Are you aware about all the tourist spots of Jharkhand } \\
\hline & & Frequency & Percent & Valid Percent & Cumulative Percent \\
\hline \multirow[t]{4}{*}{ Valid } & Maybe & 59 & 30.1 & 30.1 & 30.1 \\
\hline & No & 37 & 18.9 & 18.9 & 49.0 \\
\hline & Yes & 100 & 51.0 & 51.0 & 100.0 \\
\hline & Total & 196 & 100.0 & 100.0 & \\
\hline
\end{tabular}

Table 6.6: Frequency and percentage of respondents who are aware of the tourist spots in Jharkhand

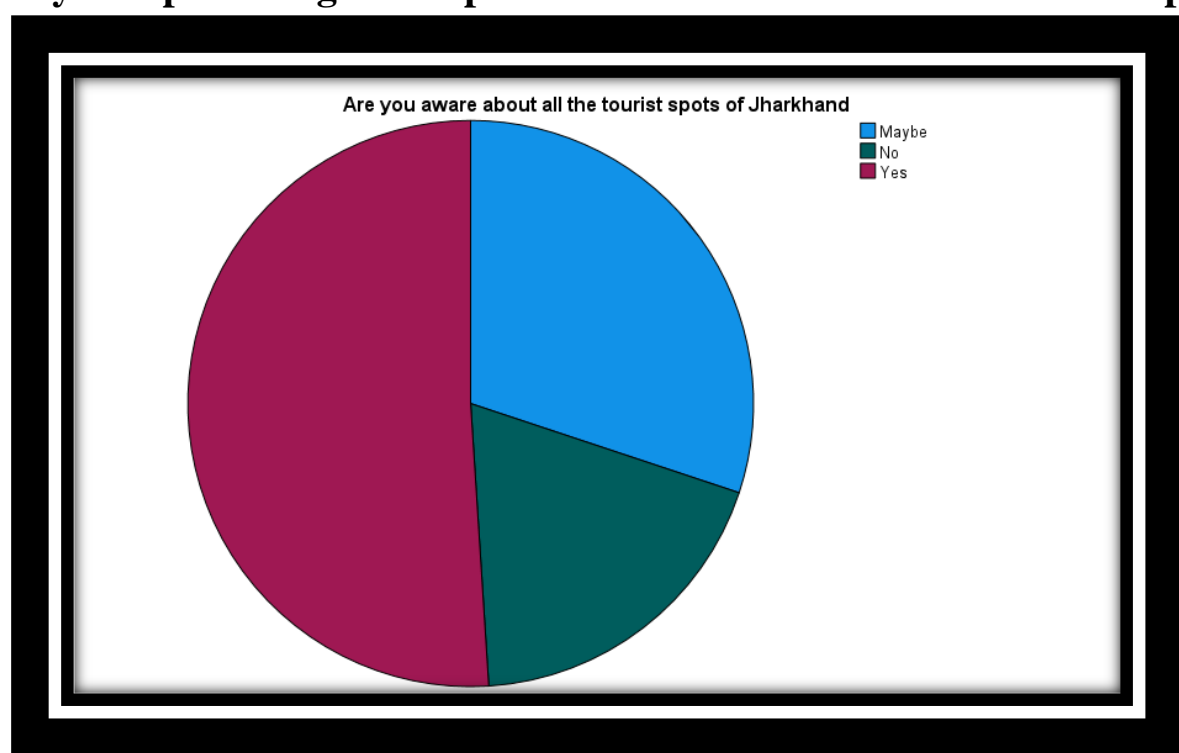

Figure 6.6: Frequency and percentage of respondents who are aware of the tourist spots in Jharkhand Have you visited some of the tourist spots of Jharkhand 


\begin{tabular}{|l|l|l|l|l|l|}
\hline \multicolumn{2}{|c|}{} & Frequency & Percent & $\begin{array}{l}\text { Valid } \\
\text { Percent }\end{array}$ & Cumulative Percent \\
\hline \multirow{3}{*}{ Valid } & Maybe & 5 & 2.6 & 2.6 & 2.6 \\
\cline { 2 - 6 } & No & 20 & 10.2 & 10.2 & 12.8 \\
\cline { 2 - 6 } & Yes & 171 & 87.2 & 87.2 & 100.0 \\
\cline { 2 - 5 } & Total & 196 & 100.0 & 100.0 & \\
\hline
\end{tabular}

Table 6.7: Frequency and percentage of respondents who have visited some of the tourist spots in Jharkhand

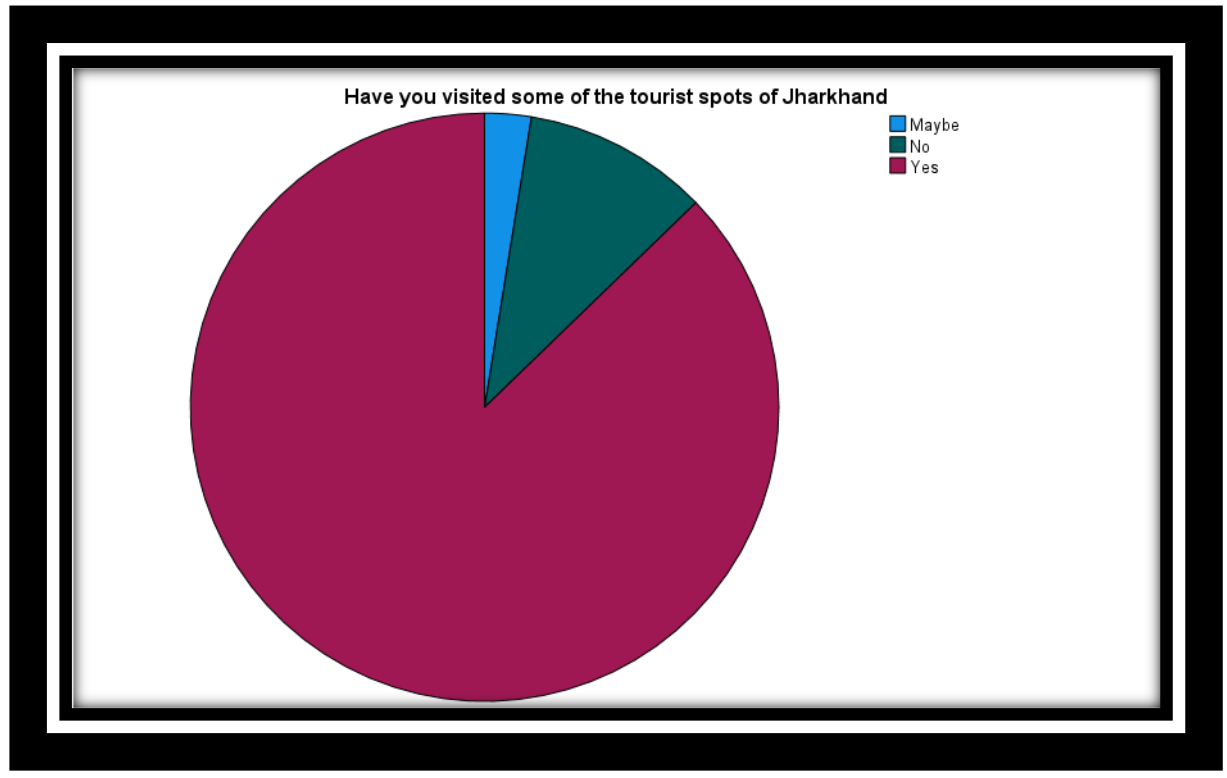

Figure 6.7: Frequency and percentage of respondents who have visited some of the tourist spots in Jharkhand

\begin{tabular}{|l|l|l|l|l|l|}
\hline \multicolumn{5}{|c|}{ Have you visited the website of Jharkhand Tourism } \\
\hline \multirow{3}{*}{ Valid } & Frequency & Percent & Valid Percent & Cumulative Percent \\
\cline { 2 - 6 } & Yes & 114 & 58.2 & 58.2 & 58.2 \\
\cline { 2 - 6 } & Total & 196 & 41.8 & 41.8 & 100.0 \\
\hline
\end{tabular}

Table 6.8: Frequency and percentage of respondents who have visited the website of Jharkhand Tourism 


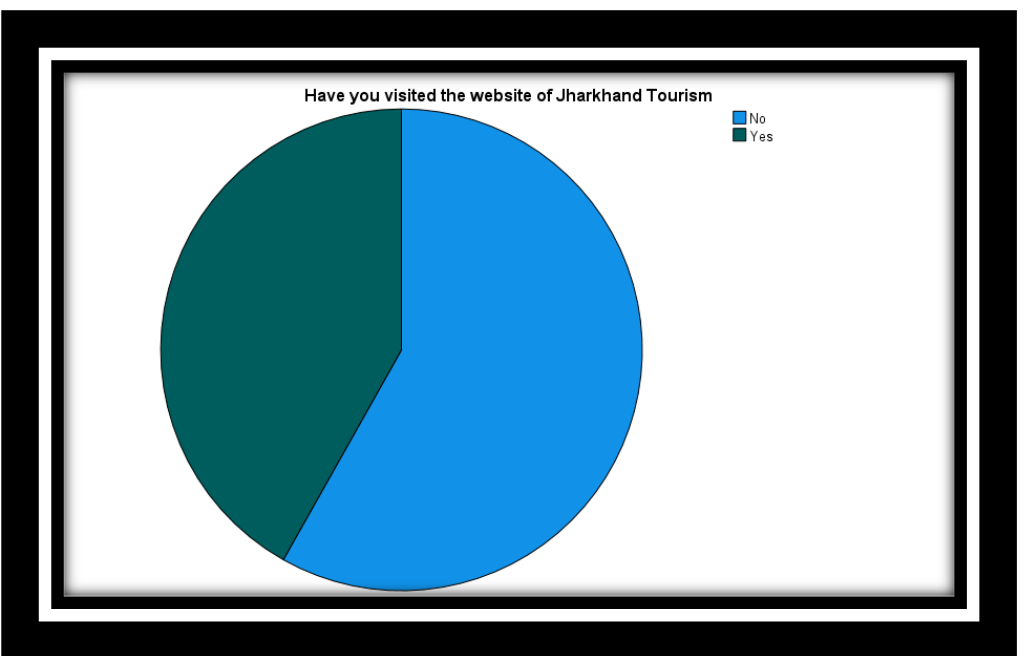

Figure 6.8: Frequency and percentage of respondents who have visited the website of Jharkhand Tourism

The Perception and interest of Generation $Z$ in Tourism, Event management and Hospitality Sector

\begin{tabular}{|l|l|l|l|l|l|}
\hline \multicolumn{6}{|c|}{ Do you think the tourist places you went were well maintained } \\
\hline \multicolumn{2}{|c|}{} & Frequency & Percent & $\begin{array}{l}\text { Valid } \\
\text { Percent }\end{array}$ & Cumulative Percent \\
\hline \multirow{3}{*}{ Valid } & Maybe & 39 & 19.9 & 19.9 & 19.9 \\
\cline { 2 - 6 } & No & 92 & 46.9 & 46.9 & 66.8 \\
\cline { 2 - 6 } & Yes & 65 & 33.2 & 33.2 & 100.0 \\
\cline { 2 - 6 } & Total & 196 & 100.0 & 100.0 & \\
\hline
\end{tabular}

Table 6.9: Frequency and percentage of respondents who believe that the tourist places were well maintained

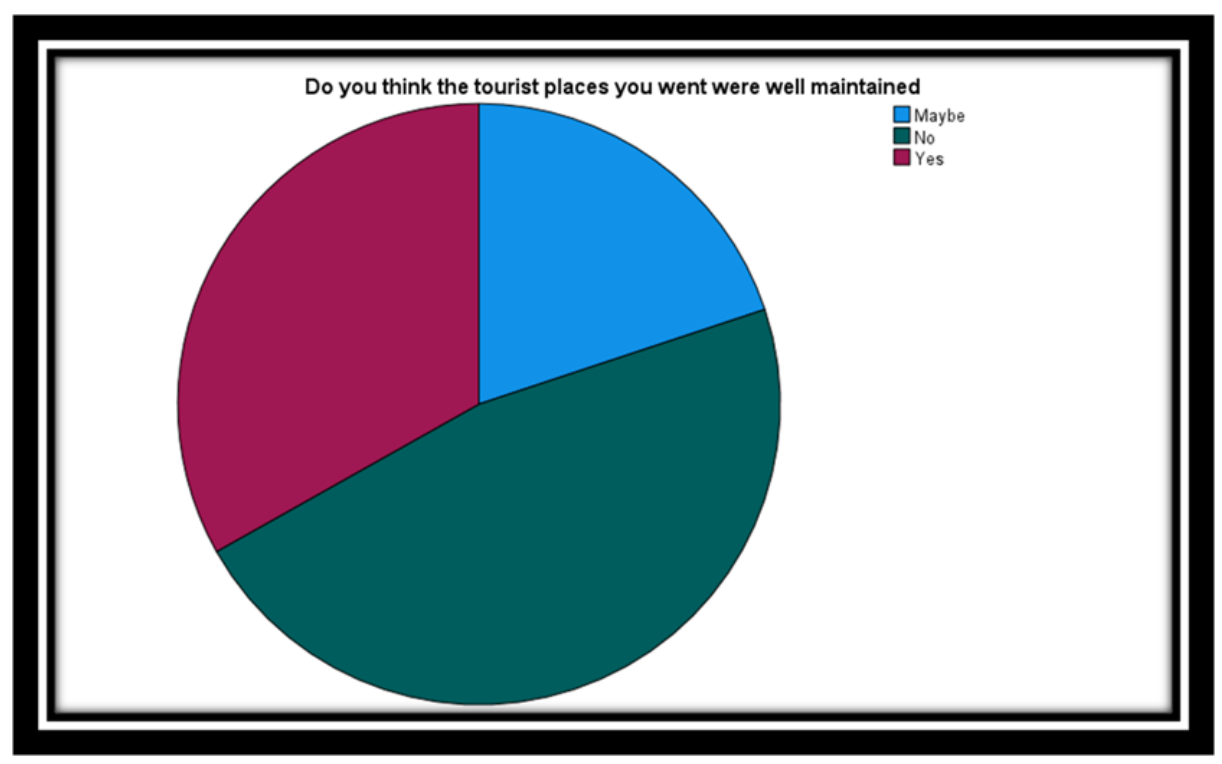

Figure 6.9: Frequency and percentage of respondents who believe that the tourist places were well maintained 


\begin{tabular}{|c|c|c|c|c|c|}
\hline \multicolumn{6}{|c|}{ Do you believe that Jharkhand Tourism would develop tremendously } \\
\hline & & Frequency & Percent & Valid Percent & Cumulative Percen \\
\hline \multirow[t]{4}{*}{ Valid } & Maybe & 38 & 19.4 & 19.4 & 19.4 \\
\hline & No & 3 & 1.5 & 1.5 & 20.9 \\
\hline & Yes & 155 & 79.1 & 79.1 & $100 .($ \\
\hline & Total & 196 & 100.0 & 100.0 & \\
\hline
\end{tabular}

Table 6.10: Frequency and percentage of respondents who believe that Jharkhand Tourism would develop tremendously

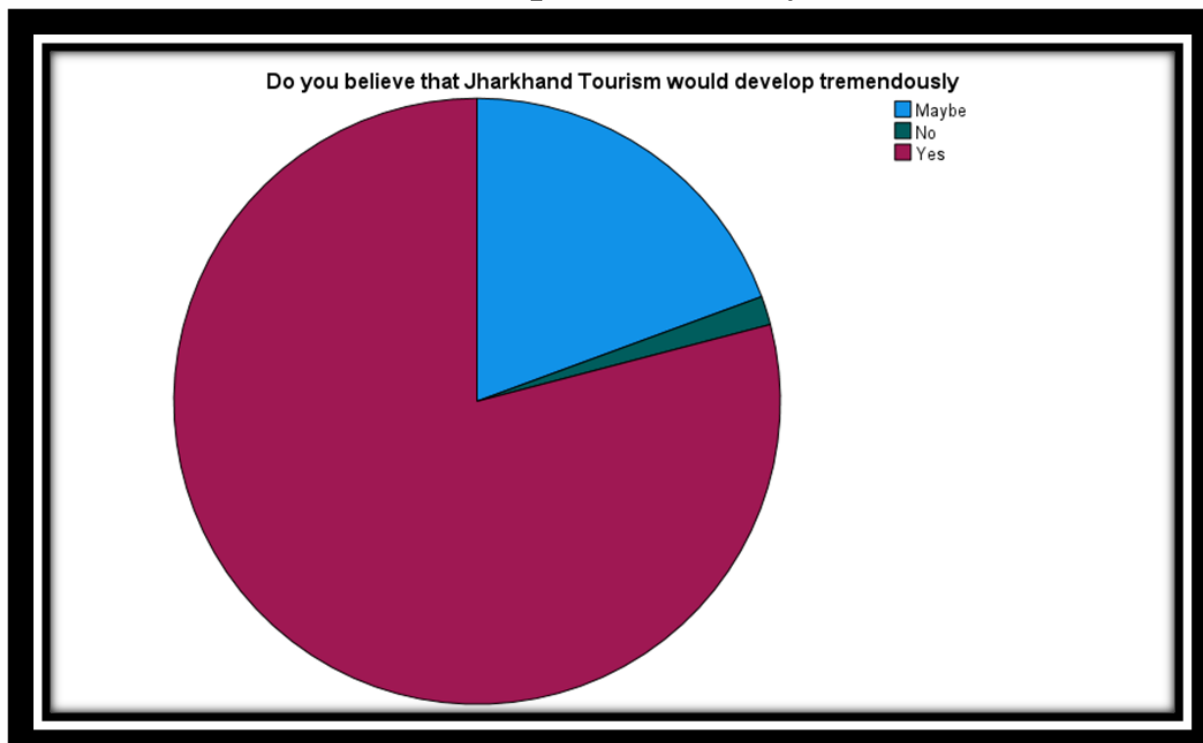

Figure 6.10: Frequency and percentage of respondents who believe that Jharkhand Tourism would develop tremendously

\section{The Perception of Generation $\mathrm{Z}$ on taking up tourism as a Career Option}

Do you find the tourism sector attractive?

\begin{tabular}{|l|l|r|r|r|r|}
\hline \multicolumn{2}{|c|}{} & Frequency & \multicolumn{1}{|c|}{ Percent } & Valid Percent & Cumulative Percent \\
\hline \multirow{4}{*}{ Valid } & Maybe & 25 & 12.8 & 12.8 & 12.8 \\
\cline { 2 - 6 } & No & 6 & 3.1 & 3.1 & 15.8 \\
\cline { 2 - 6 } & Yes & 165 & 84.2 & 84.2 & 100.0 \\
\cline { 2 - 6 } & Total & 196 & 100.0 & 100.0 & \\
\hline
\end{tabular}

Table 6.11: Frequency and percentage of respondents who found tourism Industry attractive 


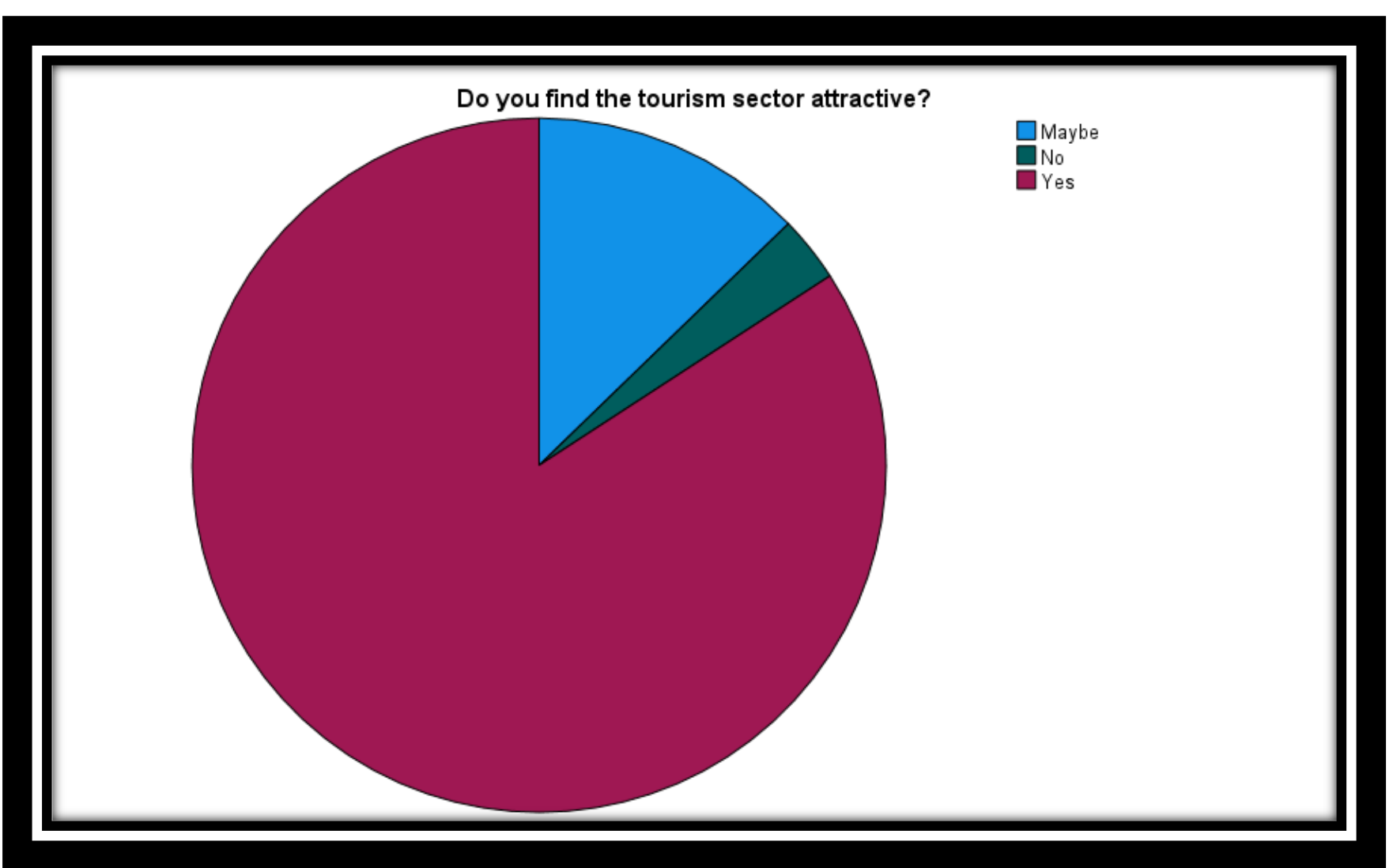

Figure 6.11: Frequency and percentage of respondents who found tourism Industry attractive

\begin{tabular}{|l|l|l|l|l|l|}
\hline \multicolumn{7}{|c|}{ Would you like to work in the tourism sector in future } \\
\hline \multirow{2}{*}{} & Frequency & Percent & Valid Percent & $\begin{array}{c}\text { Cumulative } \\
\text { Percent }\end{array}$ \\
\hline \multirow{3}{*}{ Valid } & Maybe & 62 & 31.6 & 31.6 & 31.6 \\
\cline { 2 - 6 } & No & 18 & 9.2 & 9.2 & 40.8 \\
\cline { 2 - 6 } & Yes & 116 & 59.2 & 59.2 & 100.0 \\
\cline { 2 - 6 } & Total & 196 & 100.0 & 100.0 & \\
\hline & & & & & \\
\hline
\end{tabular}

Table 6.12 : Frequency and percentage of respondents who would like to work in the tourism sector in future 


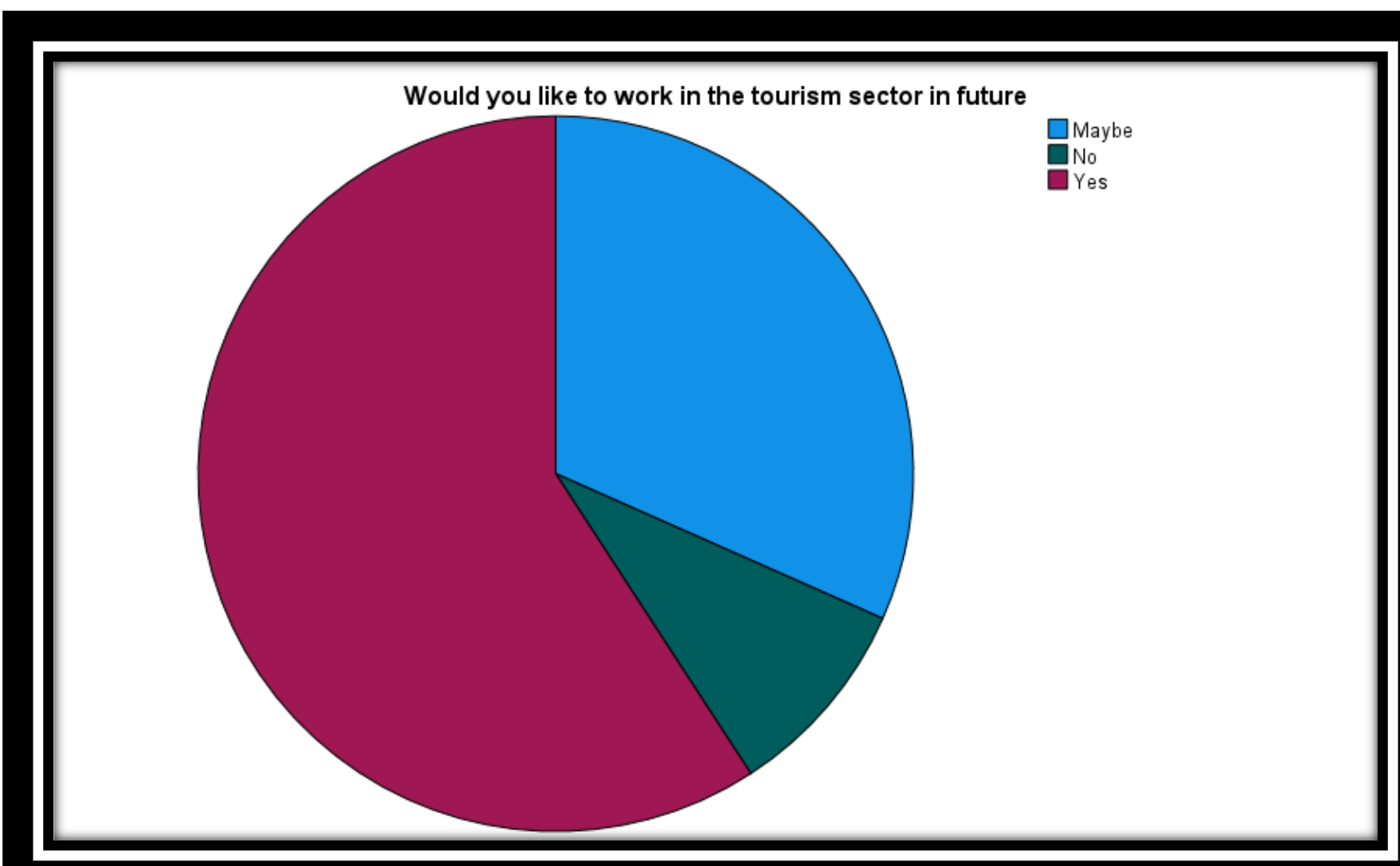

Figure 6.12: Frequency and percentage of respondents who would like to work in the tourism sector in future

\begin{tabular}{|l|l|r|r|r|r|}
\hline \multicolumn{6}{|c|}{ If working in tourism sector, where would you like to work? } \\
\hline \multicolumn{1}{|c|}{} & Frequency & \multicolumn{1}{|c|}{ Percent } & $\begin{array}{c}\text { Valid } \\
\text { Percent }\end{array}$ & Cumulative Percent \\
\hline Valid & $\begin{array}{l}\text { Private } \\
\text { Sector }\end{array}$ & 27 & 13.8 & 13.8 & 13.8 \\
\cline { 2 - 6 } & Public Sector & 94 & 48.0 & 48.0 & 100.0 \\
\cline { 2 - 6 } & $\begin{array}{l}\text { Start my own } \\
\text { venture }\end{array}$ & 75 & 38.3 & 38.3 & \\
\cline { 2 - 6 } & Total & 196 & 100.0 & 100.0 & \\
\hline
\end{tabular}

Table 6.13: Frequency and percentage of sector preferences of respondents' choices for working in tourism. 


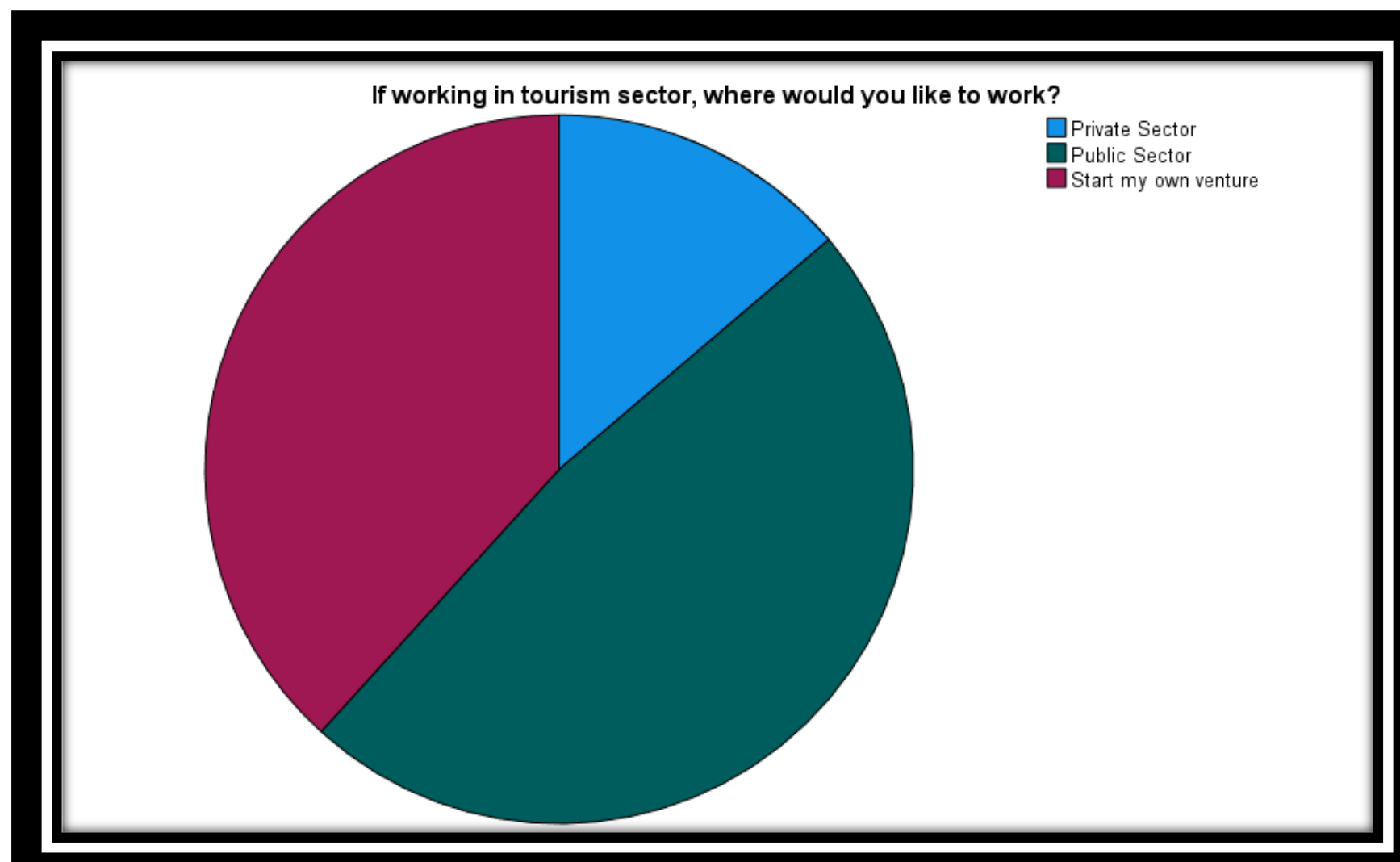

Figure 6.13: Frequency and percentage of sector preferences of respondents' choices for working in tourism.

\begin{tabular}{|c|c|c|c|c|c|}
\hline \multicolumn{6}{|c|}{$\begin{array}{l}\text { Are you aware about the various laws and regulations and advantages for an } \\
\text { entrepreneur in the tourism sector? }\end{array}$} \\
\hline & & Frequency & Percent & Valid Percent & Cumulative Percent \\
\hline \multirow[t]{3}{*}{ Valid } & No & 146 & 74.5 & 74.5 & 74.5 \\
\hline & Yes & 50 & 25.5 & 25.5 & 100.0 \\
\hline & Total & 196 & 100.0 & 100.0 & \\
\hline
\end{tabular}

Table 6.14: Frequency and percentage of respondents who are aware about the various laws and regulations and advantages for an entrepreneur in the tourism sector 


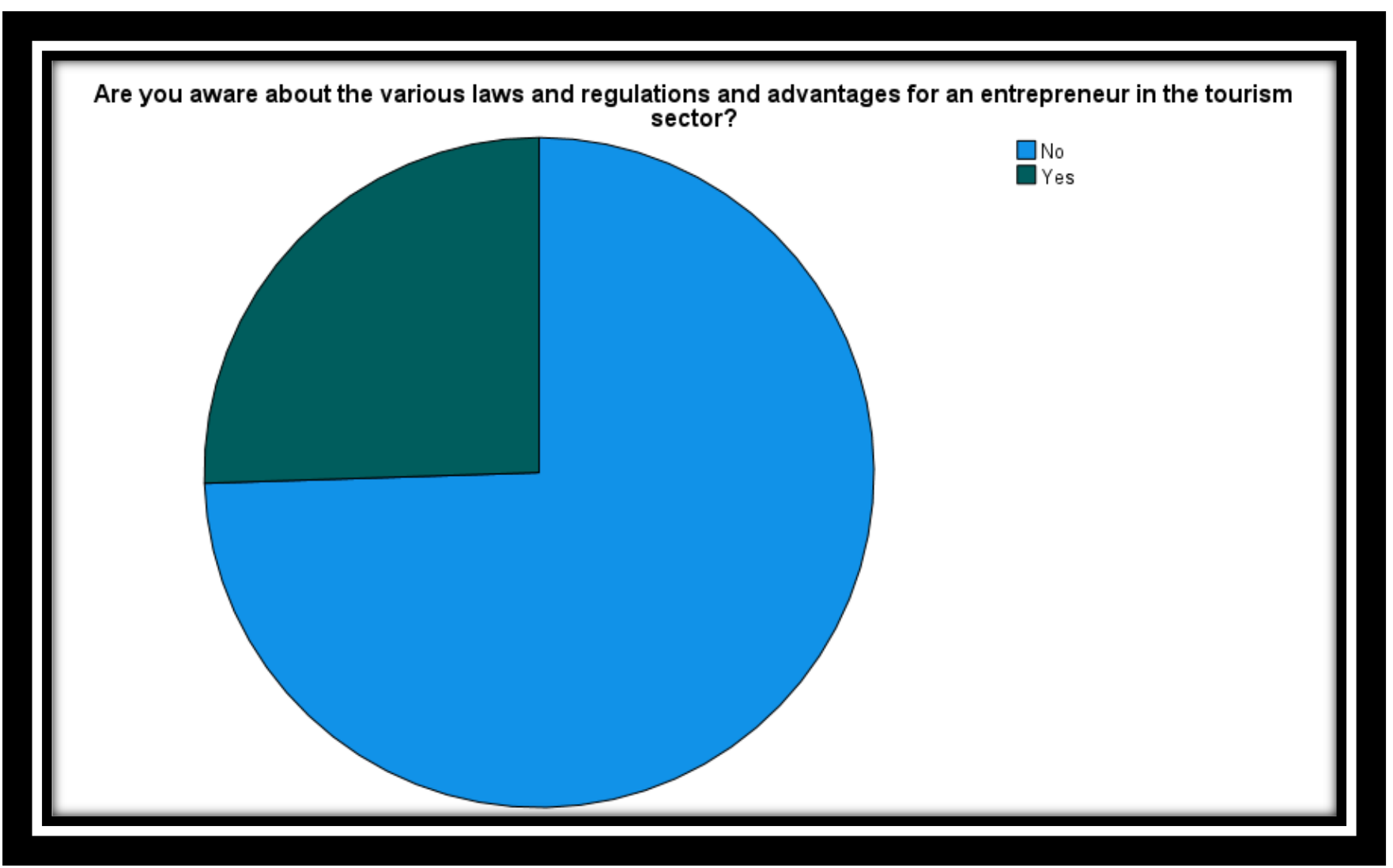

Figure 6.14: Frequency and percentage of respondents who are aware about the various laws and regulations and advantages for an entrepreneur in the tourism sector

\begin{tabular}{|l|l|l|l|l|l|}
\hline \multicolumn{6}{|c|}{ What motivates you more in tourism sector as career? } \\
\hline \multirow{2}{*}{ Valid } & Frequency & Percent & Valid Percent & Cumulative Percent \\
& $\begin{array}{l}\text { Job } \\
\text { security }\end{array}$ & 81 & 41.3 & 41.3 & 41.3 \\
\cline { 2 - 6 } & $\begin{array}{l}\text { Risk } \\
\text { taking }\end{array}$ & 115 & 58.7 & 58.7 & 100.0 \\
\cline { 2 - 6 } & Total & 196 & 100.0 & 100.0 & \\
\hline
\end{tabular}

Table 6.15: Frequency and percentage of respondents motivating factors in tourism 


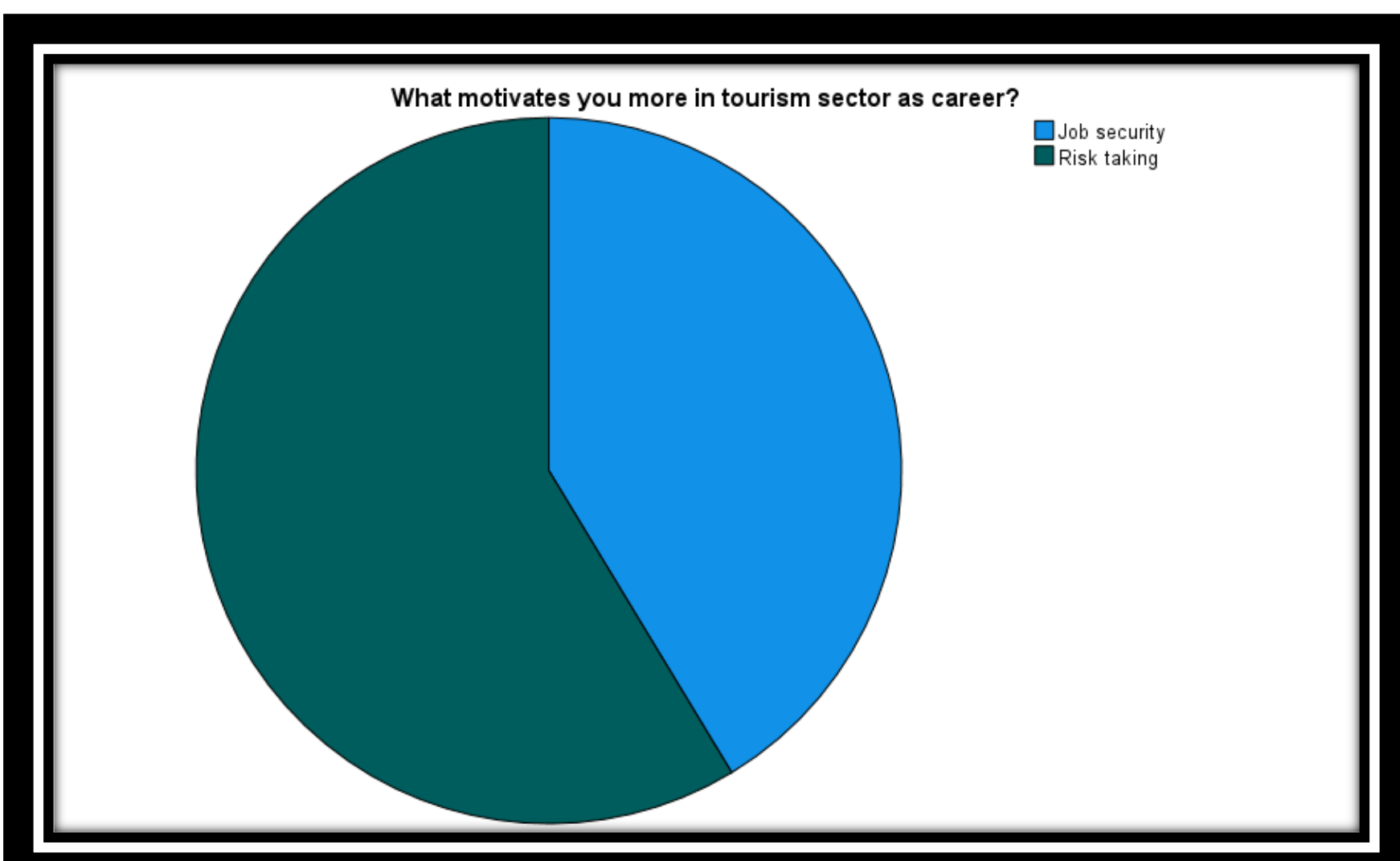

Figure 6.15: Frequency and percentage of respondents motivating factors in tourism

\begin{tabular}{|c|c|c|c|c|c|}
\hline \multicolumn{6}{|c|}{$\begin{array}{l}\text { If artificial intelligence introduced or the tourism sector is made more digital savvy, } \\
\text { would you take it up as a career? }\end{array}$} \\
\hline & & Frequency & Percent & Valid Percent & $\begin{array}{l}\text { Cumulative } \\
\text { Percent }\end{array}$ \\
\hline \multirow[t]{4}{*}{ Valid } & Maybe & 86 & 43.9 & 43.9 & 43.9 \\
\hline & No & 15 & 7.7 & 7.7 & 51.5 \\
\hline & Yes & 95 & 48.5 & 48.5 & 100.0 \\
\hline & Total & 196 & 100.0 & 100.0 & \\
\hline
\end{tabular}

Table 6.16: Frequency and percentage of sector preferences of respondents' choices for working in tourism. 


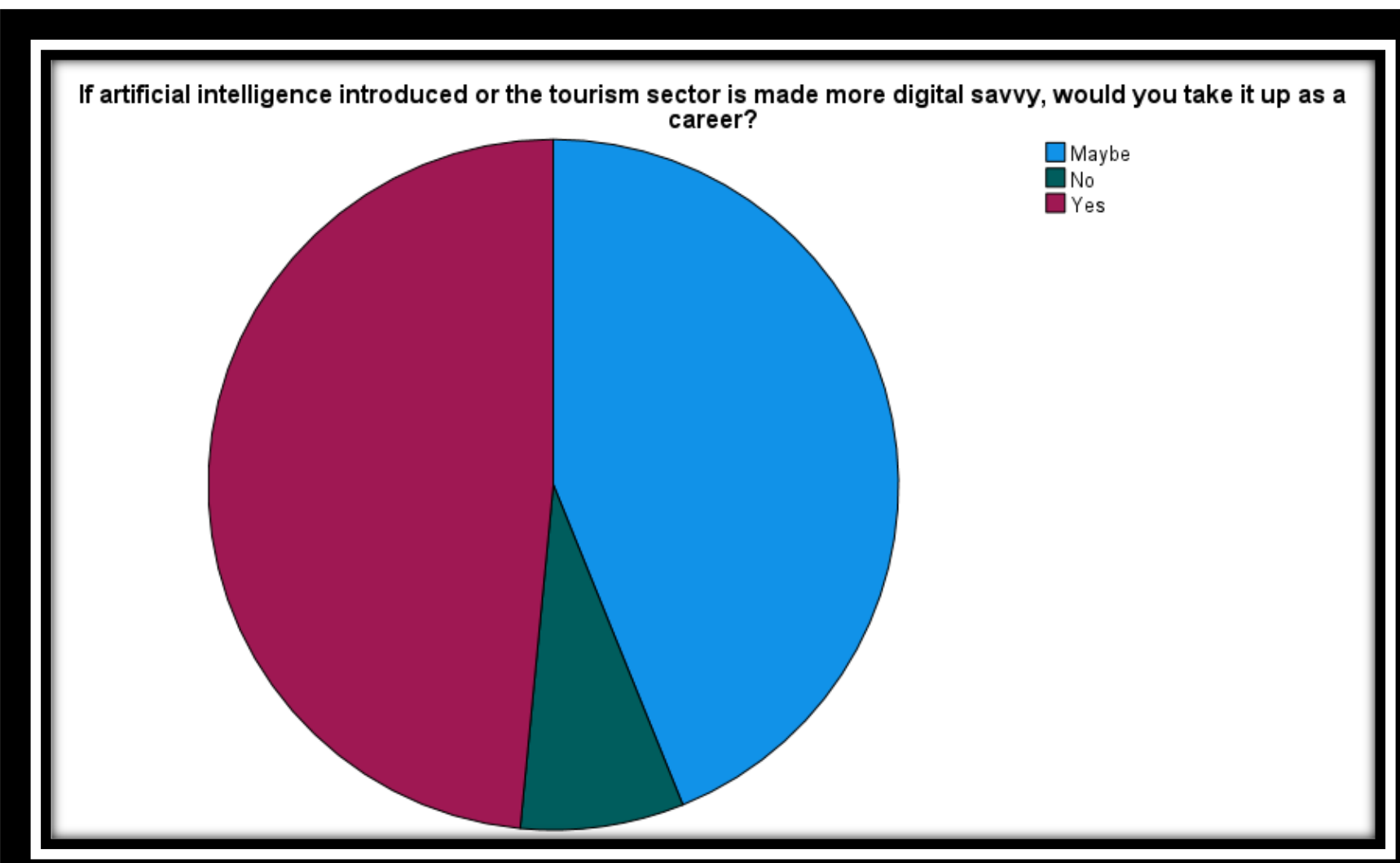

Figure 6.16: Frequency and percentage of sector preferences of respondents' choices for working in tourism.

\begin{tabular}{|c|c|c|c|c|c|}
\hline \multicolumn{6}{|c|}{ Would you take tourism as career if you have autonomy in implementing your ideas? } \\
\hline & & Frequency & Percent & Valid Percent & Cumulative Percent \\
\hline \multirow[t]{4}{*}{ Valid } & Maybe & 103 & 52.6 & 52.6 & 52.6 \\
\hline & No & 11 & 5.6 & 5.6 & 58.2 \\
\hline & Yes & 82 & 41.8 & 41.8 & 100.0 \\
\hline & Total & 196 & 100.0 & 100.0 & \\
\hline
\end{tabular}

Table 6.17: Frequency and percentage of respondents desire for autonomy in implementing ideas 


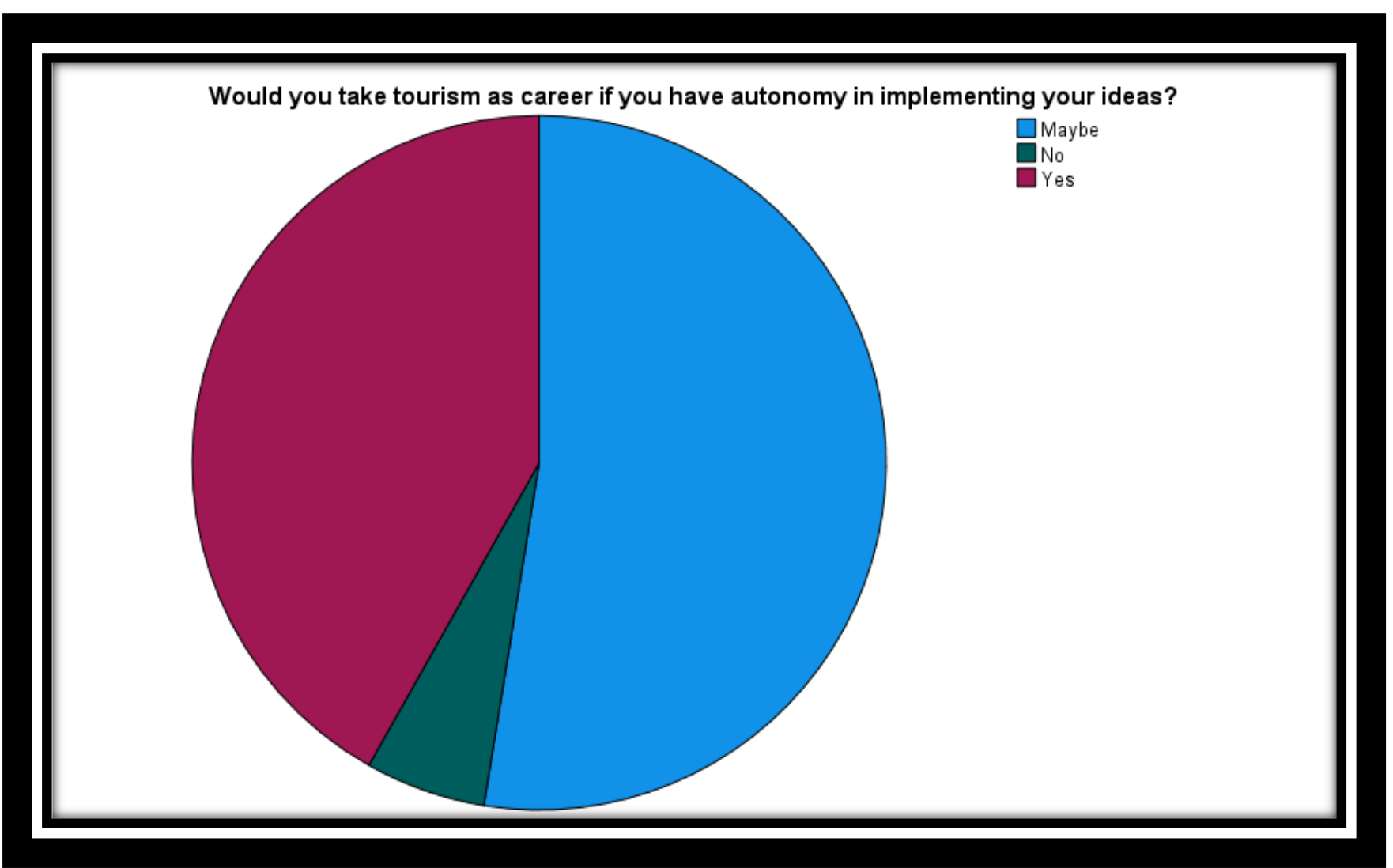

Figure 6.17: Frequency and percentage of respondents' desire for autonomy in implementing ideas

What would be the factor for you not taking up career in tourism sector?

196 responses

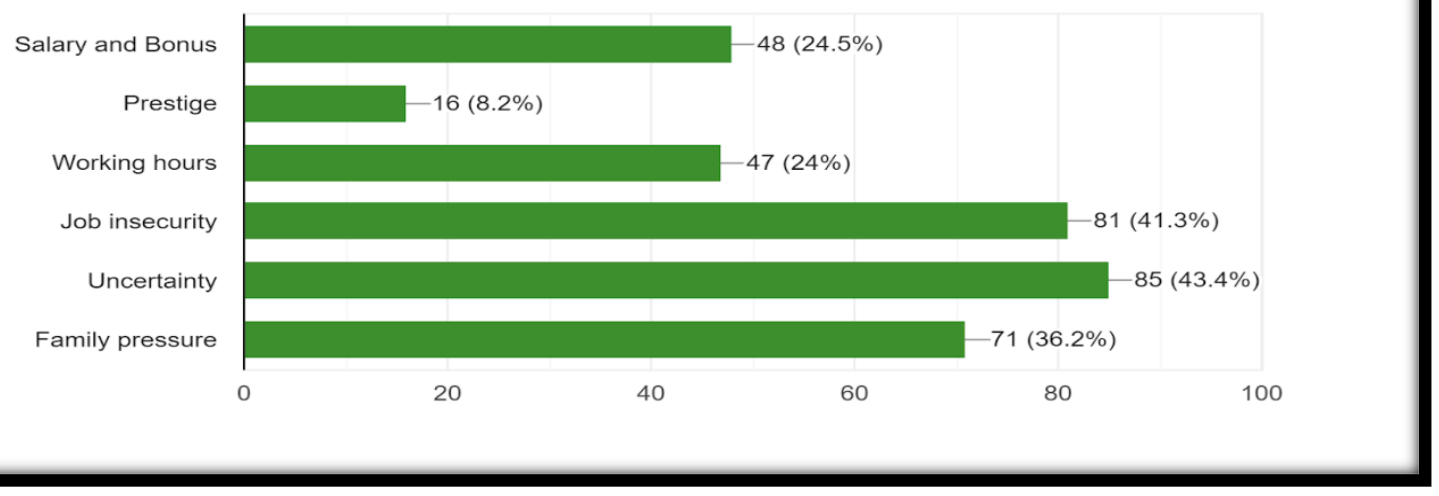

Figure 6.18: Factors for not taking up career in Tourism Sector 


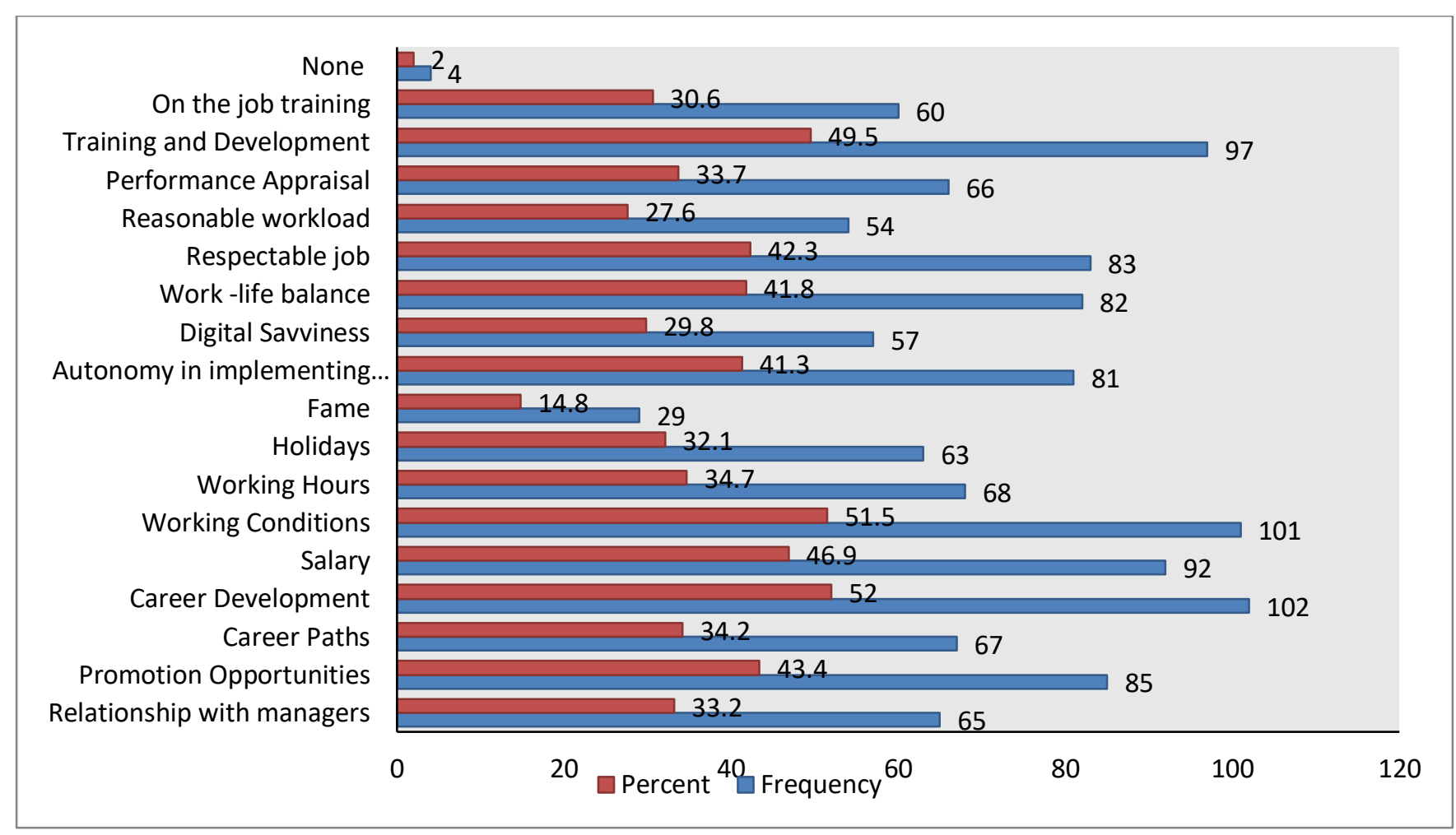

Figure 6.19: Motivators for tourism as a Career Option for Gen Z

\section{Results and Conclusion}

The results of the total 196 respondents shows that only $62.2 \%$ of the respondents have managed an event in their respective schools/College or University and only $19.9 \%$ of the respondents have been associated with some event management company. Also $12.8 \%$ of the respondents are unaware of the various programs launched by the Government for the development of tourism sector. Of the various programs, "Incredible India!" has the widest popularity.

Ranchi, was known as the hill station of Bihar and has been the capital of Jharkhand for past 20 years, still $18.9 \%$ of the respondents seem to be unaware of the tourist places of Jharkhand. Only $51 \%$ of the respondents know about tourism in their state. Though, $87.2 \%$ of the respondents have visited some or the tourist spot in the state. Jharkhand government have their own website dedicated to tourism known as "Jharkhand Tourism" and only $58.2 \%$ of the respondents have visited the website.
$46.9 \%$ of the respondents feel that the tourist places in Jharkhand are not well maintained but $79.1 \%$ of the respondents believe that there is immense scope for development of Jharkhand tourism.

$84.2 \%$ of the respondents find tourism industry attractive and $59.0 \%$ of the respondents would like to take up tourism as a career. Though $48 \%$ of the respondents would like to work in public sector, $13.8 \%$ in private sector and $3 \%$ would like to be an entrepreneur. But, only $74.5 \%$ of the respondents are aware about the rules, regulations, laws and advantages for an entrepreneur. Literature studies reveal the technological expertise, entrepreneurial mindset and diversity tolerance of the $\mathrm{Z}$ Generation. $48.5 \%$ of the respondents would like to consider tourism as a career if it is made more digital savvy and $41.8 \%$ would be interested if there was more autonomy.

The major demotivators for Gen $\mathrm{Z}$ to take up career in tourism are uncertainty $(43.4 \%$ of the respondents) and job insecurity $(41.3 \%$ of the 
respondents). Still, they are willing to take up careers in tourism sector if proper attention is paid towards the development of Jharkhand sector. Also, if due attention is paid to the employees in terms of career development (52\% of respondents), working conditions (51.5\% of respondents), training and development (49.5\% of respondents), promotion opportunities (43.4\% of respondents), respectable job (42.3\% of respondents), work - life balance (41.8\% of respondents), autonomy in implementation of ideas (41.3\% of respondents). The other factors being relationship with managers, career paths, salary, working hours, fame, holidays, digital savviness, reasonable workload, performance appraisal, on the job training and others. Despite all this around $2 \%$ of the population would still not want to take up job in the tourism sector.

The researchers come to the conclusion that despite being voracious travelers, Generation $\mathrm{Z}$ of Jharkhand state in India does not have interest in tourism in Jharkhand nor do they have interest in the career in tourism sector. But, this generation is known for their rebellious nature and their desire for autonomy. They are eager enough to take up tourism career if it is more technosavvy and they are given autonomy.

\section{Suggestions}

There is severe lack of awareness about the efforts of the Government to promote tourism. So, a regular quiz or a chapter should be included in General Knowledge books of school students which should be updated annually.

A chapter on tourism and its effects should be included in the economics book in Class IX or X, so that they building up a positive image about the industry and also develop love for their country.

Entrepreneurship, though taught in Class XI should be taught right from class VIII or IX and also a quiz or a chapter should be made in the General Knowledge book so that the Gen $\mathrm{Z}$ become aware of the benefits and the changing rules. And these chapters should be reviewed annually.

Various plays and dramas and other school activities should try to absorb all the students in one form or the other, so they become aware of the excitement this sector provides.

For inculcating the love for India, all the books of CBSE and ISCE have chapters on history, development and features of India. Similarly, it is imperative that we develop love for Jharkhand in the hearts of the natives so that they have firm believe that this state would go miles. Hence, a chapter on Jharkhand culture, tribe and Tourism should be mad compulsory in school as well as colleges.

The researchers believe that if the idea and love for this sector is inculcated in the hearts of the children soon enough, there would be more acceptance and love for this sector. And probably instead of looking for high paying job opportunities abroad, they would like to start up a new venture in Jharkhand and try to make it a place where people from other states want to come on holidays and also as a lookout for good job opportunities.

\section{Limitations}

The Gen $\mathrm{Z}$ ranges from age 8 to 24 . The children of age group 8 to 18 keep changing their career goals with time.

The lack of education is a major delimiting factor in conveying online survey.

In the pandemic times, the concept of social distancing and the prolonged closure of entertainment sectors might have an influence on their career choices and priorities.

\section{References and Bibliography}

[1] Adecco. 2015. "Generation Z vs . Millennials." Way to Work Survey. 
[2] Adekola, Bola. 2011. "Career Management As Correlates for Career Development and Job Satisfaction a Case Study of Nigerian Bank Employees." Australian Journal of Business and Management ....

[3] Anon. 2016. "Generation Z and Its Perception of Work." Cross-Cultural Management Journal.

[4] Arunmozhi, T., and a Panneerselvam. 2013. "Types of Tourism in India." International Journal of Current Research and Academic Review 1(1):84-88.

[5] Barron, Paul, Gill Maxwell, Adelina Broadbridge, and Susan Ogden. 2007. "Careers in Hospitality Management: Generation Y's Experiences and Perceptions." Journal of Hospitality and Tourism Management.

[6] Bassiouni, Dina H., and Chris Hackley. 2014. "'Generation Z' Children's Adaptation to Digital Consumer Culture: A Critical Literature Review." Journal of Customer Behaviour.

[7] Baysinger, Tim. 2015. "Good-Bye, Millennials... Hello, Generation Z." Broadcasting \& Cable.

[8] Bejtkovsky, Jiri. 2016. "The Employees of Baby Boomers Generation, Generation X, Generation $\mathrm{Y}$ and Generation $\mathrm{Z}$ in Selected Czech Corporations as Conceivers of Development and Competitiveness in Their Corporation." Journal of Competitiveness.

[9] Chillakuri, Bharat, and Rajendra Mahanandia. 2018. "Generation Z Entering the Workforce: The Need for Sustainable Strategies in Maximizing Their Talent." Human Resource Management International Digest.

[10] Csobanka, Zsuzsa Emese. 2016. "The Z Generation." Acta Technologica Dubnicae.

[11] Desai, Supriya Pavan, and Vishwanath Lele. 2017. "Correlating Internet, Social Networks and Workplace - a Case of Generation Z Students." Journal of Commerce and

www.psychologyandeducation.net
Management Thought.

[12] Dimock, Michael. 2019. "Defining Generations: Where Millennials End and Generation Z Begins." Pew Research Center.

[13] Fernández-Cruz, Francisco José, and Ma José Fernández-Díaz. 2016. “Generation z’s Teachers and Their Digital Skills." Comunicar.

[14] Fister Gale, Sarah. 2015. "Forget Millennials: ARE YOU READY FOR GENERATION Z?" Chief Learning Officer.

[15] Fratricová, Jana, and Zuzana Kirchmayer. 2018. "Barriers to Work Motivation of Generation Z." Journal of Human Resource Management.

[16] Geck, Caroline. 2006. "The Generation Z Connection: Teaching Information Literacy to the Newest Net Generation." Teacher Librarian.

[17] Goh, Edmund, and Cindy Lee. 2018. "A Workforce to Be Reckoned with: The Emerging Pivotal Generation Z Hospitality Workforce." International Journal of Hospitality Management.

[18] Goh, Edmund, and Fevzi Okumus. 2020. "Avoiding the Hospitality Workforce Bubble: Strategies to Attract and Retain Generation Z Talent in the Hospitality Workforce." Tourism Management Perspectives.

[19] Gutfreund, Jamie. 2016. "Move over, Millennials: Generation $\mathrm{Z}$ Is Changing the Consumer Landscape." Journal of Brand Strategy.

[20] Hariadi, Bambang, M. J. Dewiyani Sunarto, and Pantjawati Sudarmaningtyas. 2016. "Development of Web-Based Learning Application for Generation Z." International Journal of Evaluation and Research in Education (IJERE).

[21] Hulyk, Taylor. 2015. "MARKETING TO GEN Z: Uncovering a New World of Social Media Influencers." Franchising World. 
[22] Journal, Cross-cultural Management. 2016. "Bucharest University of Economic Studies GENERATION Z AND ITS." Cross-Cultural Management Journal.

[23] Kapil, Yagbala, and Anuja Roy. 2014. "A Critical Evaluation of Generation $\mathrm{Z}$ at Workplaces." International Journal of Social Relevance \& Concern.

[24] Kasasa. 2020. "Boomers, Gen X, Gen Y, and Gen Z Explained." Kasasa.

[25] Kvidahl, Melissa. 2015. "Generations Y and Z." Gifts \& Decorative Accessories.

[26] LEVI, ALEXANDRA. 2015. "Make Way for Generation Z." New York Times.

[27] Maloni, Michael, Mark S. Hiatt, and Stacy Campbell. 2019. "Understanding the Work Values of Gen Z Business Students." International Journal of Management Education.

[28] Mathur, Meera, and Shaheema Hameed. 2016. "A Study on Behavioural Competencies of the Z Generation." International Conference on Management and Information Systems.

[29] Merriman, Marcie. 2015. "Rise of Gen Z: New Challenge for Retailers." Ernst \& Young LLP.

[30] Montana, Patrick J., and Francis Petit. 2008. "Motivating Generation $\mathrm{X}$ and $\mathrm{Y}$ on the Job and Preparing Z." Global Journal of Business Research (GJBR).

[31] Mowforth, Steve. 2018. "“The World Is Your Oyster': Exploring the Career Conceptions of Gen-Z Students." Journal of the National Institute for Career Education and Counselling.

[32] Posnick-Goodwin, S. 2010. "Meet Generation Z." Educator.

[33] Priporas, Constantinos Vasilios, Nikolaos Stylos, and Anestis K. Fotiadis. 2017. "Generation Z Consumers' Expectations of Interactions in Smart Retailing: A Future Agenda." Computers in Human Behavior.
[34] Puiu, Silvia. 2016. "Generation Z - A New Type of Consumers." The Young Economists Journal.

[35] Richardson, Scott. 2010. “Generation Y's Perceptions and Attitudes towards a Career in Tourism and Hospitality." Journal of Human Resources in Hospitality and Tourism.

[36] Robert Half. 2015. "Get Ready for Generation Z." Enactus.

[37] Robinson, Victor Mueke, and Heike A. Schänzel. 2019. “A Tourism Inflex: Generation Z Travel Experiences." Journal of Tourism Futures.

[38] Rothman, Darla. 2014. "A Tsunami of Learners Called Generation Z." Public Safety: A State of Mind.

[39] Schroer, W. J. 2014. "Generations X, Y, Z and the Others - Cont'd." The Social Librarian.

[40] Schroer, William J., and Karen Klein. 2008. "Defining, Managing, and Marketing to Generations X, Y, and Z." The Portal.

[41] Schroth, Holly. 2019. "Are You Ready for Gen $\mathrm{Z}$ in the Workplace?" California Management Review.

[42] Seemiller, Corey, and Meghan Grace. 2017. "Generation Z: Educating and Engaging the Next Generation of Students." About Campus 22(3):21-26.

[43] Shatto, Bobbi, and Kelly Erwin. 2016. "Moving on From Millennials: Preparing for Generation Z." Journal of Continuing Education in Nursing.

[44] Shatto, Bobbi, and Kelly Erwin. 2017. "Teaching Millennials and Generation Z: Bridging the Generational Divide." Creative Nursing.

[45] Sidorcuka, Irina, and Anna Chesnovicka. 2017. "METHODS OF ATTRACTION AND RETENTION OF GENERATION Z STAFF." CBU International Conference Proceedings.

[46] Singh, A. P., and Jianguanglung Dangmei. 
2016. "UNDERSTANDING THE GENERATION Z: THE FUTURE WORKFORCE." South -Asian Journal of Multidisciplinary Studies.

[47] Singh, Anjali. 2014. "Challenges and Issues of Generation Z." IOSR Journal of Business and Management.

[48] Smith, Trianne, and Tony W. Cawthon. 2017. "Generation Z Goes to College." College Student Affairs Journal.

[49] Tapscott, Don. 1999. "Growing up Digital: The Rise of the Net Generation." NASSP Bulletin.

[50] Thomas, Yelana, and R. Srinivasan. 2016. "Emerging Shifts in Learning Paradigms-from Millenials to the Digital Natives." International Journal of Applied Engineering Research.

[51] Törőcsik, Mária, Krisztián Szücs, and Dániel Kehl. 2014. "How Generations Think: Research on Generation Z." Communicatio.

[52] Tulgan, Bruce. 2013. "Meet Generation Z: The Second Generation within the Giant " Millennial " Cohort." RainmakerThinking, Inc.

[53] Turner, Anthony. 2015. "Generation Z: Technology and Social Interest." The Journal of Individual Psychology.

[54] VITELAR, Alexandra. 2013. "Like Me: Generation $\mathrm{Z}$ and the Use of Social Media for Personal Branding." Management Dynamics in the Knowledge Economy.

[55] Wood, Stacy. 2013. "Generation Z as Consumers: Trends and Innovation." Institute for Emerging Issues: NC State University.

\section{Websites assessed}

[1] kasasa.com/articles/generations/gen-x-gen-ygen (Last retrieved on 29-10-2020)

[2] https://www.forbes.com/sites/dedehenley/2019/ 07/11/how-to-inspire-and-motivate-your-gen-zemployees (Last retrieved on 29-10-2020)
[3] https://www.raconteur.net/the-hive/gen-zworkforce-motivation-communication-purpose/ (Last retrieved on 29-10-2020)

[4] https://www.pewresearch.org/facttank/2019/01/17/where-millennials-end-andgeneration-z-begins/ft_19-01-

17_generations_2019/ (Last retrieved on 0111-2020)

[5] https://www.washingtonpost.com/education/20 19/11/16/todays-kids-may-be-digital-nativesnew-study-shows-they-arent-close-beingcomputer-literate/?outputType $=\mathrm{amp} / \quad$ (Last retrieved on 01-11-2020)

[6] https://www.dnaindia.com/india/report-10things-you-should-know-about-generation-z2328949/(Last retrieved on 01-11-2020)

[7] https://www.sparksandhoney.com/gen (Last retrieved on 01-11-2020)

[8] https://www.payscale.com/compensationtoday/2020/02/generation-z-careerexpectations-and-motivations (Last retrieved on 01-11-2020 